\title{
Alterations of Chromatin Regulators in the Pathogenesis of Urinary Bladder Urothelial Carcinoma
}

\author{
Michèle J. Hoffmann (D) and Wolfgang A. Schulz *(D) \\ Department of Urology, Medical Faculty, Heinrich Heine University Düsseldorf, 40225 Düsseldorf, Germany; \\ michele.hoffmann@hhu.de \\ * Correspondence: wolfgang.schulz@hhu.de; Tel.: +49-(0)211-81-15845
}

check for updates

Citation: Hoffmann, M.J.; Schulz, W.A. Alterations of Chromatin Regulators in the Pathogenesis of Urinary Bladder Urothelial Carcinoma. Cancers 2021, 13, 6040. https://doi.org/10.3390/ cancers 13236040

Academic Editor: José I. López

Received: 25 October 2021

Accepted: 29 November 2021

Published: 30 November 2021

Publisher's Note: MDPI stays neutral with regard to jurisdictional claims in published maps and institutional affiliations.

Copyright: (c) 2021 by the authors. Licensee MDPI, Basel, Switzerland. This article is an open access article distributed under the terms and conditions of the Creative Commons Attribution (CC BY) license (https:// creativecommons.org/licenses/by/ $4.0 /)$.
Simple Summary: Urinary bladder cancer is one of the ten major cancers worldwide, with higher incidences in males, in smokers, and in highly industrialized countries. New therapies beyond cytotoxic chemotherapy are urgently needed to improve treatment of these tumors. A better understanding of the mechanisms underlying their development may help in this regard. Recently, it was discovered that a group of proteins regulating the state of chromatin and thus gene expression is exceptionally and frequently affected by gene mutations in bladder cancers. Altered function of these mutated chromatin regulators must therefore be fundamental in their development, but how and why is poorly understood. Here we review the current knowledge on changes in chromatin regulators and discuss their possible consequences for bladder cancer development and options for new therapies.

Abstract: Urothelial carcinoma (UC) is the most frequent histological type of cancer in the urinary bladder. Genomic changes in UC activate MAPK and PI3K/AKT signal transduction pathways, which increase cell proliferation and survival, interfere with cell cycle and checkpoint control, and prevent senescence. A more recently discovered additional category of genetic changes in UC affects chromatin regulators, including histone-modifying enzymes (KMT2C, KMT2D, KDM6A, EZH2), transcription cofactors (CREBBP, EP300), and components of the chromatin remodeling complex SWI/SNF (ARID1A, SMARCA4). It is not yet well understood how these changes contribute to the development and progression of UC. Therefore, we review here the emerging knowledge on genomic and gene expression alterations of chromatin regulators and their consequences for cell differentiation, cellular plasticity, and clonal expansion during UC pathogenesis. Our analysis identifies additional relevant chromatin regulators and suggests a model for urothelial carcinogenesis as a basis for further mechanistic studies and targeted therapy development.

Keywords: urothelial carcinoma; bladder cancer; chromatin regulator; epigenetic enzyme; differentiation; plasticity; clonal expansion

\section{Introduction}

\subsection{Genomic Alterations in Urothelial Carcinoma}

Urinary bladder cancer is one of the ten major cancers worldwide with a higher incidence in males, in smokers, and in highly industrialized countries [1]. The predominant histological subtype is urothelial carcinoma (UC), with squamous cell carcinoma and further rarer entities making up less than $10 \%$ of the cases in most populations. UC comprises two large subgroups, distinguished by whether they have invaded the underlying connective tissue layers of the bladder. Non-invasive papillary UC represents most of the cases. Low-grade papillary UC is not life-threatening, but requires therapy and long-term follow-up. High-grade papillary UC and especially carcinoma in situ have a higher risk of progressing to invasive carcinomas. Of note, tumors of various stages and grades may develop not only metachronously but also synchronously. Invasive carcinomas comprise 
about one-quarter of the cases at presentation and require radical surgery, often combined with neo-adjuvant or adjuvant chemotherapy. Metastatic UC remains invariably lethal, despite systemic chemotherapy and more recently introduced immunotherapies [2].

Genomic changes in UC alter three regulatory systems in a rather consistent manner (reviewed in [3-5]). (1) The MAPK and PI3K/AKT signal transduction pathways that direct cell proliferation and survival are activated by mutations, amplification, or rearrangements of receptor tyrosine kinase genes, most frequently FGFR3, by oncogenic RAS mutations, by alternate PIK3CA oncogenic mutations or PTEN loss, or by other mutations in MAPK and PI3K/AKT pathway components. (2) Cell cycle and checkpoint control are disturbed by TP53 inactivation as well as RB1 mutations and deletions, which are both much more frequent in invasive than in papillary $\mathrm{UC}$, or by homozygous deletion, promoter hypermethylation, and mutations in CDKN2A, encoding regulators of both TP53 and RB1, which are observed across all stages of the disease. Additional relevant changes in cell cycle control include inactivating mutations in CDKN1A (encoding p21 ${ }^{\mathrm{CIP} 1}$ ) and ATM as well as amplification of CCND1 encoding Cyclin D1. (3) Loss of function of TP53 and RB1 is expected to impede the establishment of senescence in response to replication stress and genomic instability. In addition, telomerase is activated in almost all UC, independent of grade and stage, most frequently by activating mutations in the $h T E R T$ promoter.

Collectively, these changes would have been considered sufficient to explain the pathogenesis of urothelial cancers. It came therefore as a surprise when mutations in chromatin regulator genes were discovered to represent another consistent alteration in UC [6,7]. The vast majority of UC cases contain mutations in at least one of these genes (see Section 2). In particular, mutations in chromatin regulator genes are even found regularly in papillary $\mathrm{UC}$, which often remain near-diploid and have a comparatively low number of genomic changes. UC thus presents with one of the highest frequencies of genetic alterations in chromatin regulator genes among all cancer types. Obviously, altered function of chromatin regulators must be fundamental for the pathogenesis of UC. Why this is so is, however, poorly understood to date.

In the present review, we will therefore attempt to delineate the scope of the alterations in chromatin regulators in UC (Section 2) and to outline possible functional explanations for their high prevalence (Section 3).

\subsection{Urothelial Differentiation and Molecular Subtypes of Urothelial Carcinoma}

The source of urothelial carcinoma is the urothelium, a specialized, stratified epithelium lining the urinary tract from the renal pelvis into the urethra. UC can manifest in any section of the urothelium, but most tumors develop in the bladder. Of note, UC of the upper urinary tract presents with overall similar genomic alterations, albeit at different frequencies $[8,9]$. Moreover, tumors deficient in DNA mismatch repair occur exclusively in the upper urinary tract.

The adult urothelium is usually quiescent, with one of the slowest turnover rates among mammalian epithelia. However, following injury, its cells are capable of resuming proliferation when rapid regeneration is needed, e.g., after mechanical injury or bacterial infection, allowing complete restoration within $72 \mathrm{~h} \mathrm{[10-12].}$

The urothelium comprises three different layers of cells with increasing morphological complexity and differentiation: basal cells, intermediate cells, and the superficial umbrella cells that form the major barrier towards the urine in the bladder lumen (reviewed in [13]). The basal cells are attached to the basement membrane and are small with condensed nuclei, in keeping with their rather undifferentiated state. They express basal cell marker proteins like cytokeratin 5 (KRT5) and TP63, but not the specific marker proteins of urothelial differentiation like cytokeratins $7,8,18$, and 20 or uroplakins. A subset of basal cells (estimated variously as $0.5-10 \%$ ) also expresses KRT14. Under homeostatic conditions, these may be the only mitotically active cells with some stem cell characteristics [14] Cells in the rat bladder retaining labeling for more than one year also reside in the basal layer [15]. They may therefore constitute progenitor cells at the origin of clonal units, 
maintaining and regenerating the urothelium [16], although this interpretation needs further investigation [17].

Intermediate cells, in keeping with their designation, have an intermediate degree of characteristics and express KRT7, little if any KRT5, and no KRT14. At least a subset of intermediate cells can proliferate during acute injury and contribute to regeneration of the urothelial layer, whereas the response to chronic injury depends more on basal cells [17-19].

The luminal superficial umbrella cells are larger, multinucleated, and terminally differentiated. They express uroplakins, specialized proteins required for the barrier function of the urothelium, and specifically KRT20. To accommodate varying filling volumes in the bladder, the thickness of the epithelium can adapt by intermediate cells shifting against each other, and umbrella cells can adjust their apical surface area [20].

Urothelial regeneration following injury is stimulated by several growth factors from urothelial cells and mesenchymal cells in the underlying submucosal connective tissue. Injured urothelium secretes EGF-like growth factors (such as TGF $\alpha$, HB-EGF, and amphiregulin) to stimulate proliferation. Signaling through FGF receptors activated by FGF2 contributes to this process. Reciprocal epithelial-mesenchymal signaling, with basal cells secreting $\mathrm{SHH}$ to stimulate WNT secretion in mesenchymal cells, is likewise activated during rapid regeneration [21,22].

Differentiation in the urothelium is regulated by a network of transcription factors, which is still incompletely understood $[23,24]$. These transcription factors are thought to interact with various chromatin regulators to establish stable and adaptive transcription patterns, but few studies have addressed these interactions in the urothelium. However, since the urothelial transcription factor network bears similarities with the networks regulating epidermal and ductal mammary differentiation, observations from these tissues may extend to the urothelium (see below).

The TP63 gene encodes various isoforms of a p53 family transcription factor. The most prominent isoforms are the full length variant TAp63 and the $\mathrm{N}$-terminal truncated $\triangle \mathrm{Np} 63$ isoform with opposing functions in the regulation of differentiation and proliferation that carry over into tumors with a basal cell phenotype. The $\Delta \mathrm{Np} 63$ variant is the most strongly expressed isoform in the basal layer of stratified epithelia. It maintains the proliferation potential of progenitor cells and controls epithelial morphogenesis through recruitment of epigenetic regulators, including repressive complexes containing histone deacetylases (HDAC) $[10,25] . \Delta \mathrm{Np} 63$ can in particular interact with the SWI/SNF chromatin remodeling complex.

The transcription factor ZNF750 controls epithelial tissue homeostasis by repression of progenitor genes and upregulation of differentiation genes through interaction with the transcription factor KLF4 and chromatin regulators like KDM1A and HDAC1 [26]. ZNF750 expression is in turn regulated by TP63 [27]. The Grainyhead transcription factor GRHL3 interacts with other chromatin regulators, including JMJD3 (KDM6B) and BRG1/BRM (SMARCA4/A2) and the histone methyltransferase MLL2 (KMT2D) [28]. These factors have been investigated in more detail for their function in epidermal differentiation but are also implicated in urothelial homeostasis [29].

The nuclear receptor PPAR $\gamma$ has been shown to promote specifically urothelial over squamous differentiation. In mice, Pparg mutations prevented maturation of superficial umbrella cells, and Pparg inactivation in basal cells resulted in squamous rather than urothelial differentiation. Further, Pparg mutant mice presented with persistent inflammation in the urinary tract and activated NFkB signaling. Accordingly, Pparg re-expression prevents squamous differentiation [30]. Additional transcription factors like Elf3, Grhl3, and Klf5 and specific Gata factors were identified as determinants of urothelial specification in mice $[25,31-33]$.

To investigate the transcription factors involved in human urothelial differentiation, a model system using cultures of normal human urothelial (NHU) cells has been employed [34]. These cells, usually isolated from the ureter or, less commonly, the bladder urothelium, proliferate in specific serum-free media under the influence of EGF-like and 
FGF factors [35]. Notably, they acquire a basal cell phenotype with increased plasticity, and a substantial fraction of the cells express the stem cell marker KRT14. Accordingly, they can be induced by different protocols towards squamous or urothelial differentiation.

Induction of urothelial differentiation in this model system is achieved by blocking EGFR signaling and activating PPAR $\gamma$. This leads to the expression of intermediate transcription factors specifying the differentiated urothelial cell phenotype, including forkhead box A1 (FOXA1), interferon regulatory factor 1 (IRF1), GATA-binding protein 3 (GATA3), and E74-like ETS transcription factor 3 (ELF3) [36]. Concomitantly, the cells acquire markers of luminal urothelial differentiation like KRT20 and uroplakins. An alternative protocol for differentiation employs treatment with serum and calcium with similar consequences but more pronounced stratification. Thus, a network of transcription factors, including PPAR $\gamma$, IRF1, FOXA1, ELF3, and GATA3, lies at the core of urothelial differentiation [29].

Reflecting their increased plasticity, a different protocol applying high dose calcium only results in the stratification and squamous differentiation of primary urothelial cells. This state is characterized by expression of KRT5/6, KRT14, and S100A9 and further epidermal differentiation markers like Loricrin, Filaggrin, and Involucrin [37]. Of note, this protocol can also be successfully applied to HBLAK cells, a non-transformed urothelial cell line [38].

Characteristics of basal and luminal differentiation states are reflected in the recently defined molecular subtypes of urothelial carcinoma. The recent consensus classifies invasive urothelial carcinomas into six subclasses, mainly on the basis of gene expression patterns [39]. The subclasses differ, moreover, by their predominant driver mutations, prognosis, and response to therapy, albeit with substantial overlaps.

Luminal subtypes are characterized by the expression of markers of urothelial differentiation, including uroplakins and KRT20, which reflect the activity of the transcription factors FOXA1, GATA3, and PPAR $\gamma$. This applies in particular to the luminal papillary subtype characterized by oncogenic mutations activating the growth factor receptor FGFR3 and CDKN2A deletions. In contrast, mutations in TP53 (and RB1) are relatively rare in this subtype. The frequency of mutations in the KDM6A histone demethylase gene is likewise highest in this subtype. Importantly, this subtype resembles the predominant molecular subtype of non-invasive papillary urothelial tumors [40]. Luminal papillary cancers have the best prognosis of all invasive UCs, and even metastatic cases often respond well to treatment with recently introduced FGFR3 inhibitor drugs (reviewed in [41,42]).

The second luminal subtype (luminal unstable) contains the largest number of genomic changes and displays the highest cell cycle activity of all subtypes. TP53 mutations and $E R B B 2$ amplification are prevalent in this subtype, but also mutations and gene fusions activating the lineage-specific oncogenes PPARG and RXRA (encoding the standard PPAR $\gamma$ heterodimerization partner) [43].

A third, rarer luminal subtype (luminal non-specified) contains more stromal cells, especially fibroblasts. Mutations in the ELF3 gene, which encodes a transcription factor acting downstream of PPAR $\gamma$ in urothelial differentiation [32], are enriched in this subtype. Of note, FGFR3 mutations are less common in the luminal unstable and luminal nonspecified subtypes than in luminal papillary cancers [7,39].

Stromal-rich tumors contain an even higher fraction of various stromal cell types, but additionally of immune cells. Urothelial differentiation markers are less prominently expressed.

The basal-squamous subtype (BASQ) is characterized by the expression of differentiation markers of basal urothelial cells (see above) and a variable expression of markers of squamous differentiation. Regions with histological squamous differentiation are detectable in up to $40 \%$ of these tumors. Gene expression patterns indicate active EGFR and STAT3 signaling. TP53 and RB1 mutations are frequent. BASQ tumors often contain many immune cells, including cytotoxic T-cells.

Neuroendocrine-like cancers constitute the rarest subtype. Most are morphologically identifiable as 'small cell carcinomas', while others can only be assigned to this subtype by their expression patterns. Typical of neuroendocrine-like cancers, TP53 and RB1 are 
concomitantly inactivated. Neuroendocrine-like cancers have the worst prognosis of all UC subtypes, followed by BASQ tumors [39].

Squamous cell carcinoma (SCC) of the bladder is regarded as a distinct histologic entity from urothelial carcinoma. These rarer cancers usually arise following chronic inflammation of the bladder, caused, e.g., by Schistosoma infection or catherization. Genomic alterations in SCC are however similar to those in BASQ UC, suggesting that they arise by a similar mechanism. Presumably, aberrant urothelial regeneration during chronic inflammation results in squamous metaplasia that can progress to SCC [10]. The plasticity of urothelial precursor cells in vitro (see above) supports this contention.

\subsection{Chromatin Regulators}

Regulation of the chromatin structure is required for transcription regulation, genome replication, mitosis, DNA repair, formation of constitutive heterochromatin, and other nuclear processes. Cellular plasticity, lineage choices, and cell differentiation are controlled by dynamic epigenetic mechanisms. At the core of epigenetic regulation, establishment, maintenance, and changes of cell differentiation states are associated with chromatin states, delineating the basic transcription patterns of each cell type. These long-term stable chromatin configurations are then dynamically adapted to various functional requirements, including cell replication, specific cell function, metabolic demands and various stresses (reviewed in [44-47]).

Chromatin regulators encompass a variety of factors acting on DNA, histones, and other components of chromatin and interacting among themselves. DNA methylation at cytosines in CpG-dinucleotides is a largely long-term modification that is established by DNA methyltransferases (the 'writers') and removed by DNA demethylases (the 'erasers') and additional mechanisms, such as 'passive' dilution by replication without remethylation (reviewed in [48]). It is recognized positively ('read') by proteins like MBD2, which typically act as components of repressor complexes, but cytosine methylation also prevents binding of transcriptional activators to CpG-containing binding sites, to very different degrees (reviewed in [49]). Additionally, DNA methyltransferases and demethylases interact directly with other types of chromatin regulators. Alterations of DNA methylation patterns are frequent in UC. Pathogenesis and functional consequences of these alterations and their use in bladder cancer diagnostics have been reviewed elsewhere [50-54].

Histone modifications mediate both stable and dynamic chromatin states. For instance, heterochromatin, active and inactive enhancers, active and repressed genes, promoters, and gene bodies are each distinguished by patterns of specific histone modifications, including lysine and arginine methylation and lysine acetylation. Phosphorylation of histones is particularly relevant for DNA repair and mitosis. Overall, more than 200 different histone modifications are known (listed in [55]), and their number is still increasing. Like DNA methylation, histone modifications involve writers and erasers and are interpreted by readers, which include many proteins that also act as writers or erasers, allowing forward and feedback regulatory circuits.

Acetylation of different lysine residues, especially in the $\mathrm{N}$-terminal non-helical domains of histones $\mathrm{H} 3$ and $\mathrm{H} 4$, is generally a marker of open chromatin and in particular associated with actively transcribed genes and active enhancers. Histone acetylation is regulated by a dynamic interplay of histone acetyltransferases (HATs) and histone deacetylases (HDACs). Many HATs are transcriptional co-activators, like p300 (gene EP300) and CBP (gene: $C R E B B P$ ). Notably, like these two proteins, many HATs have paralogs with overlapping but not identical functions, like the pairs GCN5/PCAF (KAT2A/KAT2B) and MYST3/MYST4 (also known as MOZ/MORF, encoded by KAT6A/KAT6B). In its function as a co-activator, each HAT interacts with a set of cell-type-specific or ubiquitous transcription factors to establish and maintain open chromatin structures at enhancers (especially p300) and promoters. Other HATs function mostly in the deposition of newly formed nucleosomes following DNA replication or in DNA repair as components of multiprotein complexes. Histone acetylation is removed by hydrolysis catalyzed by histone deacetylases 
(HDACs). Among the 18 HDACs in human cells, subclass I enzymes (comprising HDAC1, 2,3 , and 8) catalyze the bulk of histone deacetylation. However, HDACs have non-histone protein substrates as well, and some are located predominantly in the cytoplasm or shuttle between cytoplasm and nucleus (like subclass IIA enzymes HDAC4, 5, 7, and 9). Acetylated histones are specifically recognized by a large number of nuclear proteins containing PHD domains or bromodomains (reviewed in [56]).

The function of lysine methylation depends on the site and the number of methyl groups. Histone methylation is in general less dynamic than acetylation. For instance, trimethylation of lysine 9 ( $\mathrm{H} 3 \mathrm{~K} 9 \mathrm{me} 3)$ is characteristic of constitutive heterochromatin, whereas H3K4me3 marks active promoters. H3K27me3 is a repressive modification found especially at genes regulated during development, lineage choice, or cell differentiation. Methylation at H3K36 distinguishes actively transcribed gene bodies. In a similar fashion, methylation at various sites of other canonical and of variant histones (such as H3.3, $\mathrm{H} 2 \mathrm{AZ}$, and $\mathrm{H} 2 \mathrm{AX}$ ) is associated with different chromatin states. Accordingly, different histone methylases from several enzyme and gene families attach methyl groups, and conversely, histone demethylases with various specificities remove them. Most histone demethylases, with KDM1A as a notable exception, are dioxygenases (like the TET family of DNA demethylases) and use $\alpha$-ketoglutarate as a co-substrate. In the context of UC, the KMT2 family and EZH2 have received most attention. The KMT2 H3K4 histone methylases (also known as MLLs) are components of multiprotein complexes that activate transcription at promoters and enhancers (reviewed in [57]). EZH2 is the catalytic subunit of the polycomb repressor complex PRC2 (which may alternatively contain its paralog EZH1), which mediates H3K27 trimethylation and gene repression. Removal of methyl groups at H3K27 is initiated by the KDM6 demethylases KDM6A (also known as UTX) and KDM6B (also known as JMJD3). The third family member, UTY, has little enzymatic activity, but can substitute for KDM6A in some contexts [58,59].

Chromatin remodelers form another class of chromatin regulators. They interact with histone-modifying proteins and DNA-binding transcription factors to establish and change overall chromatin structure. In particular, several multiprotein complexes move nucleosomes along DNA, thereby creating denser packaging or more open structures. Chromatin remodelers like the SWI/SNF complex are therefore required for both gene repression and activation, but remodelers are also necessary for DNA repair and replication or for exchange of histone variants (like the SWR1 complex). In the context of cancer, the SWI/SNF complex has received most attention, as several of its components are mutated at significant frequencies in many cancer types, including UC (reviewed in [60-62]). The best recognized function of this complex is the regulation of gene activation at transcriptional start sites, where repositioning of nucleosomes facilitates the access of transcriptional activators and the basal transcription machinery. The SWI/SNF complex is also notable for interacting with many nuclear receptors, including the estrogen receptor, androgen receptor, and PPAR $\gamma$. Nucleosome repositioning by SWI/SNF is driven by ATP through the ATPases BRG1 (gene SMARCA4) or BRM (gene SMARCA2) in different isoforms of the complex. ARID1A and ARID1B are further essential components present in alternative isoforms. ARID1A is particularly frequently inactivated in cancer [63,64]. Helicase activity is provided by the HELLS subunit (also known as LSH, gene SMARCA6). A number of chromodomain protein (CHD) subunits are named for a domain recognizing methylated histones.

At a higher level of organization, chromatin looping defines local segments along the DNA strand, within which enhancers and promoters can interact. It is organized among other factors by the DNA-binding 'isolator' protein CTCF and by the cohesin complex (reviewed in $[65,66]$ ). One cohesin component, STAG2, is inactivated by mutations in up to $20 \%$ of UC $[7,67,68]$. This inactivation was initially assumed to contribute to the pronounced chromosomal instability seen in many invasive UC. However, no consistent correlation with the degree of chromosomal instability could be confirmed $[67,69]$, and recent findings in other cancer types suggest an impact on transcription regulation through 
chromatin organization [70,71]. Of note, STAG2 and another frequently mutated chromatin regulator gene, $K D M 6 A$, are located on the $\mathrm{X}$-chromosome, which may contribute to the overall male gender bias of UC [40].

Histone variants provide another option for chromatin regulation; they mark and support the function of specific genome regions such as centromeres, telomeres, active genes, and regions involved in nucleolar functions. H2AX is essential for DNA repair. Only a few studies to date have addressed the function of histone variants in UC [72,73]. As it is still difficult to assess their impact, we will not deal further with histone variants in the present review. Rather, we will primarily consider histone-modifiers (including erasers) and chromatin remodelers as core chromatin regulators (see also introductory remarks to Section 2).

In addition, various types of non-coding RNAs are involved in the regulation of chromatin states and gene expression. Long non-coding RNAs act at many steps of gene expression regulation, and several are involved in the establishment and maintenance of chromatin structures (reviewed in [74]). Altered expression of several lncRNAs has been detected and confirmed in UC, as reviewed elsewhere. Micro-RNAs are primarily posttranscriptional regulators influencing chromatin states only indirectly. Both overexpression and down-regulation of specific miRNAs has been reported in UC, and the functions of these changes have been widely studied, although not all reports are consistent. Several recent reviews on expression and functions of miRNAs in UC are available [75,76]. Of note, with further research and validation of preliminary studies, lncRNAs or miRNAs may provide particularly valuable biomarkers in UC diagnostics.

\section{Alterations of Chromatin Regulator Genes in Urothelial Carcinoma}

\subsection{Introductory Remarks}

Several studies have consistently revealed that chromatin regulators, specifically chromatin remodelers and histone-modifying enzymes, are exceptionally frequently mutated in UC $[6,7,68,77]$, suggesting that subsequent epigenetic changes drive urothelial tumorigenesis and cancer progression (reviewed in $[78,79]$ ). In the TCGA study on muscle-invasive UC [7], about $90 \%$ of the cancers carried one or more mutations in KDM6A (encoding histone demethylase UTX), KMT2C, KMT2D (encoding histone methyltransferases MLL2 and MLL3), CREBBP, EP300 (histone acetyltransferases), and ARID1A (a SWI/SNF component).

To obtain a comprehensive overview of genomic alterations affecting chromatin regulators in UC, we downloaded a list of 720 genes categorized as chromatin regulators in the EpiFactors database, a manually curated database for epigenetic regulators and their complexes [80]. Note that the definition of epigenetic regulators in the Epifactors database is somewhat broader than that outlined in Section 1.3 by including selected transcription and RNA-processing factors and DNA methylation writers and erasers. In order to avoid introducing bias, we did not perform an annotation prior to the following analysis. All 720 genes were searched for mutations, copy number alterations (CNA, restricted to amplifications or homozygous deletions), and expression differences in bladder cancer tissues in comparison to normal bladder tissues in the TCGA dataset (BLCA). To this end, public TCGA expression data were downloaded using the Morpheus tool generated by the Broad Institute (https: / / software.broadinstitute.org/Morpheus, accessed on 31 August 2021). Expression values for the 720 epigenetic regulators were extracted for tumor and normal samples, and fold-change expression across tumor samples as compared to normal samples was calculated. Data on mutations and genetic changes in the TCGA BLCA dataset were obtained from Robertson et al. [7] via BioPortal [81,82] and filtered for results on the 720 chromatin regulators.

\subsection{Mutations}

Among the 720 chromatin regulator genes, 665 contained nonsynonymous mutations in at least one of the $412 \mathrm{UC}$ samples; 187 were mutated in at least 10 tumors. Table 1 lists the top 25 most frequently mutated genes; a complete listing can be found in the 
Supplementary Materials (Data file S1). As reported by the TCGA authors [7], the most frequently mutated genes were the COMPASS components KMT2C, KMT2D, and KDM6A, and the SWI/SNF subunit ARID1A, along with TP53 (a transcription factor), each in more than 100 tumors. Genes mutated in at least 10 tumors encoded many additional histone writers, erasers, and components of chromatin remodeling and polycomb complexes, as well as a few transcription factors, coactivators, and corepressors, including FOXA1 in 14 cases, PPARGC1A (a PPAR $\gamma$ coactivator) in 19 cases, and RB1 (a corepressor) in 83 cases. Each of the three TET DNA demethylase genes was mutated in at least 10 cancers, most frequently TET1, in 30 cases. DNMT3A and DNMT1 were each affected by mutations in 10 cases. This latter result suggests that DNA methylation changes in UC [50-54] may in some cases be caused by genetic alterations of DNA methylation writers and erasers.

Table 1. Top 25 chromatin regulator genes affected by mutations in urothelial carcinoma.

\begin{tabular}{|c|c|c|c|c|}
\hline $\begin{array}{l}\text { HGNC Gene } \\
\text { Symbol }\end{array}$ & HGNC Gene Name & Function & $\begin{array}{l}\text { Sample Number } \\
\text { with Mutations }\end{array}$ & Cytoband \\
\hline TP53 & tumor protein $\mathrm{p} 53$ & $\begin{array}{l}\text { Histone modification write } \\
\text { cofactor, TF }\end{array}$ & 230 & $17 \mathrm{p} 13.1$ \\
\hline$K M T 2 D$ & $\begin{array}{l}\text { lysine }(\mathrm{K}) \text {-specific } \\
\text { methyltransferase } 2 \mathrm{D}\end{array}$ & Histone modification write & 160 & $12 q 13.12$ \\
\hline ARID1A & $\begin{array}{c}\text { AT rich interactive domain 1A } \\
\text { (SWI-like) }\end{array}$ & Chromatin remodeling cofactor & 130 & 1p36.11 \\
\hline KDM6A & lysine (K)-specific demethylase 6A & Histone modification erase & 117 & Xp11.3 \\
\hline KMT2C & $\begin{array}{l}\text { lysine }(\mathrm{K}) \text {-specific } \\
\text { methyltransferase } 2 \mathrm{C}\end{array}$ & Histone modification write & 103 & $7 q 36.1$ \\
\hline$R B 1$ & retinoblastoma 1 & $\begin{array}{l}\text { Chromatin remodeling, Histone } \\
\text { modification write }\end{array}$ & 83 & $13 q 14.2$ \\
\hline EP300 & E1A binding protein p300 & Histone modification write & 80 & $22 q 13.2$ \\
\hline ATM & ATM serine/threonine kinase & Histone modification write & 71 & $11 \mathrm{q} 22.3$ \\
\hline KMT2A & $\begin{array}{l}\text { lysine }(\mathrm{K}) \text {-specific } \\
\text { methyltransferase } 2 \mathrm{~A}\end{array}$ & Histone modification write & 59 & $11 \mathrm{q} 23.3$ \\
\hline CREBBP & CREB binding protein & Histone modification write & 53 & $16 \mathrm{p} 13.3$ \\
\hline$B R C A 2$ & breast cancer 2 , early onset & Histone modification write & 52 & $13 q 13.1$ \\
\hline ASXL2 & $\begin{array}{l}\text { additional sex combs like } \\
\text { transcriptional regulator } 2\end{array}$ & Histone modification read & 47 & $2 \mathrm{p} 23.3$ \\
\hline NCOR1 & nuclear receptor corepressor 1 & $\begin{array}{l}\text { Histone modification erase } \\
\text { cofactor }\end{array}$ & 44 & 17p12-p11.2 \\
\hline TRRAP & $\begin{array}{l}\text { transformation/transcription } \\
\text { domain-associated protein }\end{array}$ & $\begin{array}{l}\text { Histone modification write } \\
\text { cofactor }\end{array}$ & 41 & $7 \mathrm{q} 22.1$ \\
\hline SRCAP & $\begin{array}{l}\text { Snf2-related CREBBP } \\
\text { activator protein }\end{array}$ & $\begin{array}{l}\text { Chromatin remodeling, Histone } \\
\text { modification erase }\end{array}$ & 38 & $16 \mathrm{p} 11.2$ \\
\hline CHD7 & $\begin{array}{c}\text { chromodomain helicase DNA } \\
\text { binding protein } 7\end{array}$ & Chromatin remodeling & 37 & $8 \mathrm{q} 12.2$ \\
\hline$M G A$ & MGA, MAX dimerization protein & $\begin{array}{l}\text { Histone modification write } \\
\text { cofactor, TF }\end{array}$ & 36 & $15 q 15.1$ \\
\hline$A T R$ & ATR serine/threonine kinase & Histone modification write & 36 & $3 q 23$ \\
\hline ASH1L & $\begin{array}{c}\text { ash1 (absent, small, or } \\
\text { homeotic)-like (Drosophila) }\end{array}$ & Histone modification write & 36 & $1 \mathrm{q} 22$ \\
\hline PRKDC & $\begin{array}{l}\text { protein kinase, DNA-activated, } \\
\text { catalytic polypeptide }\end{array}$ & Histone modification write & 35 & $8 \mathrm{q} 11.21$ \\
\hline CHD6 & $\begin{array}{c}\text { chromodomain helicase DNA } \\
\text { binding protein } 6\end{array}$ & Chromatin remodeling & 35 & $20 \mathrm{q} 12$ \\
\hline SETD2 & SET domain containing 2 & Histone modification write & 33 & $3 p 21.31$ \\
\hline CHD2 & $\begin{array}{c}\text { chromodomain helicase DNA } \\
\text { binding protein } 2\end{array}$ & Chromatin remodeling & 33 & $15 q 26.1$ \\
\hline$A R I D 1 B$ & $\begin{array}{l}\text { AT rich interactive domain 1B } \\
\text { (SWI1-like) }\end{array}$ & Histone modification write & 32 & $6 q 25.3$ \\
\hline SPEN & $\begin{array}{c}\text { spen family } \\
\text { transcriptional repressor }\end{array}$ & $\begin{array}{c}\text { Histone modification erase } \\
\text { cofactor, } \mathrm{TF}\end{array}$ & 32 & 1p36.21-p36.13 \\
\hline
\end{tabular}


These numbers have to be considered in the light of the high mutation rate in UC (up to $10 / \mathrm{Mbp}$ ), with 100-200 genes mutated in typical cases. In addition, our present analysis does not distinguish the type of mutation in the respective genes, such as missense, nonsense, or other types of truncating mutations. In evaluating the significance of mutations, the ratio of nonsynonymous to synonymous mutations would also have to be considered for each individual gene (see ref. [7], supplement). Nevertheless, our review indicates that various chromatin regulators are affected by mutations in individual UC, in addition to those formally identified as significantly mutated genes in the overall TCGA cohort, such as KMT2C, KMT2D, KDM6A, ARID1A, and others.

A total of 438 chromatin regulator genes were amplified in at least one UC, with 147 loci amplified in at least 10 cancers. Table 2 lists the top 25 most frequently amplified genes; a complete listing can be found in the Supplementary Materials (Data file S1). Amplified regions harboring more than one chromatin regulator gene were predominantly located on chromosome arms known to be gained in UC $[4,83]$ and included especially $1 p, 8 q, 5 p$, and 10p (which are therefore over-represented in Table 2) as well as at lower frequencies $1 q, 3 p$ (distal)/3q, 6p (the well-described 6p22 amplicon [84] with the DEK gene [85]), 11q, 16p, 17q, 19, and 20q. Interestingly, the most frequently amplified chromatin regulator gene was USP21 at 1q23.3, which encodes a H2A deubiquitinase. The enzyme furthermore acts on a large number of non-histone proteins, including EZH2 [86] and BRCA2 [87]. While investigated in other cancers, few studies on the function of USP21 in UC are available to date. In one study, the 1q23 amplicon has been described as being associated with metastasis and poor prognosis [88]. Another amplicon at 1q21.3 contains SETDB1 as previously highlighted by others [89]. The encoded H3K9 methyltransferase is essential for the growth of many cancer types and considered as a therapeutic target [90]. Its function in UC is however unexplored. At 8q22.3, YWHAZ and UBR5 were frequently amplified. $Y W H A Z$ encodes a 14-3-3 family protein with multiple functions that is overexpressed due to amplification in different cancer types, including bladder cancer [91]. The E3 ubiquitin ligase UBR5 is likewise overexpressed in different cancers due to gene amplification [92] but has not yet been studied explicitly in bladder cancer. Among its various functions is regulating ubiquitination of chromatin during DNA repair [93]. Whether these two factors impinge on UC pathogenesis as chromatin regulators or through their various other activities is unknown. Other amplified genes of interest are discussed in subsequent sections.

A total of 225 chromatin regulator genes were homozygous deleted in at least one UC, with 39 homozygous deleted in at least 10 cases. Table 3 lists the top 25 most frequently homozygous deleted genes; a complete listing can be found in the Supplementary Materials (Data file S1). Homozygous deletions were predominantly located on chromosomal arms known to be subject to losses in UC $[4,83,94]$. Several genes each were affected on $2 q$, 8p21, 9p24 (including $J A K 2$, doubling as a histone kinase in addition to its function in STAT signaling), 13q (two distinct regions encompassing BRCA2 or FOXO1 and RB1, respectively), 16p (including CREBBP), 17p (two regions encompassing NCOR1 and TP53, respectively), and 22q13 (encompassing BRD1 and HDAC10). Homozygous deletions at $3 \mathrm{p}, 4 \mathrm{q}, 14 \mathrm{q}$, and $18 \mathrm{q}$ each contained only a single chromatin regulator gene, namely FOXP1, ING2, RCOR1, and ZNF516, respectively. RB1 was most frequently subject to homozygous deletions in 37 cancers, followed by three genes on $8 p$. 
Table 2. Top 25 chromatin regulator genes amplified in urothelial carcinoma.

\begin{tabular}{|c|c|c|c|c|}
\hline $\begin{array}{l}\text { HGNC Gene } \\
\text { Symbol }\end{array}$ & HGNC Gene Name & Function & $\begin{array}{c}\text { Sample Number } \\
\text { with Amplifications }\end{array}$ & Cytoband \\
\hline USP21 & ubiquitin specific peptidase 21 & Histone modification erase & 69 & $1 \mathrm{q} 23.3$ \\
\hline YWHAZ & $\begin{array}{l}\text { tyrosine 3-monooxygenase/tryptophan } \\
\text { 5-monooxygenase activation protein, zeta }\end{array}$ & Histone modification read & 69 & $8 \mathrm{q} 22.3$ \\
\hline UBR5 & $\begin{array}{l}\text { ubiquitin protein ligase E3 component } \\
\text { n-recognin } 5\end{array}$ & $\begin{array}{l}\text { Chromatin remodeling, Histone } \\
\text { modification write cofactor }\end{array}$ & 58 & $8 \mathrm{q} 22.3$ \\
\hline TADA1 & transcriptional adaptor 1 & Histone chaperone & 46 & $1 \mathrm{q} 24.1$ \\
\hline SETDB1 & SET domain, bifurcated 1 & Histone modification write & 44 & $1 \mathrm{q} 21.3$ \\
\hline BRD9 & $\begin{array}{c}\text { bromodomain containing } 9 \\
\text { TAF3 RNA polymerase II, TATA box }\end{array}$ & Histone modification read & 42 & $5 p 15.33$ \\
\hline TAF3 & $\begin{array}{l}\text { binding protein (TBP)-associated factor, } \\
140 \mathrm{kDa}\end{array}$ & Histone modification read & 41 & 10p14 \\
\hline CHD1L & $\begin{array}{l}\text { chromodomain helicase DNA binding } \\
\text { protein 1-like }\end{array}$ & Chromatin remodeling & 40 & $1 \mathrm{q} 21.1$ \\
\hline PRKAB2 & $\begin{array}{c}\text { protein kinase, AMP-activated, beta } 2 \\
\text { non-catalytic subunit }\end{array}$ & Histone modification write cofactor & 40 & 1q21.1 \\
\hline VPS72 & $\begin{array}{l}\text { vacuolar protein sorting } 72 \text { homolog (S. } \\
\text { cerevisiae) }\end{array}$ & Histone modification write cofactor & 40 & $1 \mathrm{q} 21.3$ \\
\hline ZNF687 & zinc finger protein 687 & Histone modification erase cofactor & 40 & $1 \mathrm{q} 21.3$ \\
\hline POGZ & $\begin{array}{c}\text { pogo transposable element with ZNF } \\
\text { domain }\end{array}$ & Histone modification read & 39 & $1 \mathrm{q} 21.3$ \\
\hline ANP32E & $\begin{array}{l}\text { acidic (leucine-rich) nuclear } \\
\text { phosphoprotein } 32 \text { family, member E }\end{array}$ & $\begin{array}{l}\text { Histone chaperone, Histone } \\
\text { modification read }\end{array}$ & 38 & $1 \mathrm{q} 21.2$ \\
\hline TDRKH & tudor and $\mathrm{KH}$ domain containing & RNA modification & 38 & $1 \mathrm{q} 21.3$ \\
\hline SETD5 & SET domain containing 5 & Histone modification write & 38 & $3 \mathrm{p} 25.3$ \\
\hline$A S H 2 L$ & $\begin{array}{l}\text { ash2 (absent, small, or homeotic)-like } \\
\text { (Drosophila) }\end{array}$ & Histone modification write cofactor & 38 & $8 \mathrm{p} 11.23$ \\
\hline HDAC11 & histone deacetylase 11 & Histone modification erase & 37 & $3 p 25.1$ \\
\hline BRPF1 & bromodomain and PHD finger containing, 1 & Histone modification read & 37 & $3 p 25.3$ \\
\hline TADA3 & transcriptional adaptor 3 & Histone modification write cofactor & 37 & $3 p 25.3$ \\
\hline ATAD2 & ATPase family, AAA domain containing 2 & Chromatin remodeling & 35 & $8 \mathrm{q} 24.13$ \\
\hline ZHX1 & zinc fingers and homeoboxes 1 & $\begin{array}{l}\text { Chromatin remodeling, Histone } \\
\text { modification write cofactor }\end{array}$ & 35 & $8 \mathrm{q} 24.13$ \\
\hline SFMBT2 & Scm-like with four mbt domains 2 & $\begin{array}{l}\text { Histone modification read, } \\
\text { Polycomb group (PcG) protein, } \mathrm{TF}\end{array}$ & 35 & $10 \mathrm{p} 14$ \\
\hline NIPBL & Nipped-B homolog (Drosophila) & Histone modification erase cofactor & 33 & $5 \mathrm{p} 13.2$ \\
\hline YEATS4 & YEATS domain containing 4 & Histone modification write cofactor & 33 & $12 q 15$ \\
\hline RAD54B & RAD54 homolog B (S. cerevisiae) & Chromatin remodeling & 32 & $8 \mathrm{q} 22.1$ \\
\hline
\end{tabular}

In addition to those genes discussed in detail in the following subsection, several are good candidates for further studies. NCOR1 was identified as a significantly mutated gene by several studies [6]. It encodes a co-repressor interacting with many nuclear receptors, influencing especially metabolism and immune responses. Experimental modulation of NCOR1 has been shown to affect PPAR $\gamma$ signaling in prostate and UC cancer cells $[95,96]$, but the relevance of this interaction for UC development and progression remains to be further elucidated. RCOR1 is best characterized as a component of another corepressor complex, Co-REST, which is involved in lineage choice and differentiation. No specific studies on urothelial cells are published, but intriguingly, RCOR1 is required in epidermal progenitor (basal) cells [26]. ZNF516 likewise interacts with CoREST [97], especially to repress EGFR (see also below). In contrast, BRD1 is a bromodomain-containing co-activator interacting especially with the HBO1 complex containing MYST3 (KAT2A) to acetylate histones [98]. No dedicated investigations on BRD1 in UC are available. In addition to FOXA1, several other members of the FOX family are implicated in UC (reviewed in [24]), but FOXP1 and FOXO1 (see also below) are not well studied. HDAC10 is a class IIB histone deacetylase that is weakly expressed in urothelial cells [99]. The ING2 protein contributes to nucleotide excision repair and cell cycle control in a TP53-dependent manner; polymorphisms in the gene may influence bladder cancer risk [100]. 
Table 3. Top 25 chromatin regulator genes affected by homozygous deletions in urothelial carcinoma.

\begin{tabular}{|c|c|c|c|c|}
\hline $\begin{array}{l}\text { HGNC Gene } \\
\text { Symbol }\end{array}$ & HGNC Gene Name & Function & $\begin{array}{l}\text { Sample Number with } \\
\text { Homozygous Deletions }\end{array}$ & Cytoband \\
\hline$R B 1$ & retinoblastoma 1 & $\begin{array}{l}\text { Chromatin remodeling, Histone modification } \\
\text { write }\end{array}$ & 37 & $13 q 14.2$ \\
\hline NPM2 & Nucleophosmin nucleoplasmin 2 & Histone chaperone & 30 & $8 \mathrm{p} 21.3$ \\
\hline$H R$ & hair growth associated & Histone modification erase & 29 & $8 \mathrm{p} 21.3$ \\
\hline SETDB2 & SET domain, bifurcated 2 & Histone modification write & 29 & $13 q 14.2$ \\
\hline ELP3 & elongator acetyltransferase complex subunit 3 & Histone modification write & 24 & $8 \mathrm{p} 21.1$ \\
\hline ERBB4 & v-erb-b2 avian erythroblastic leukemia viral oncogene homolog 4 & Histone modification cofactor & 20 & $2 q 34$ \\
\hline PSIP1 & PC4 and SFRS1 interacting protein 1 & Chromatin remodeling & 17 & $9 \mathrm{p} 22.3$ \\
\hline FOXO1 & forkhead box $\mathrm{O} 1$ & $\mathrm{TF}$ & 17 & $13 q 14.11$ \\
\hline ING5 & inhibitor of growth family, member 5 & Histone modification read & 16 & $2 q 37.3$ \\
\hline$J A K 2$ & Janus kinase 2 & Histone modification write & 16 & $9 \mathrm{p} 24.1$ \\
\hline KDM4C & lysine $(\mathrm{K})$-specific demethylase $4 \mathrm{C}$ & Histone modification erase & 16 & $9 \mathrm{p} 24.1$ \\
\hline UHRF2 & $\begin{array}{l}\text { ubiquitin-like with PHD and ring finger domains 2, E3 ubiquitin } \\
\text { protein ligase }\end{array}$ & Histone modification read & 16 & $9 \mathrm{p} 24.1$ \\
\hline TDRD3 & tudor domain containing 3 & Histone modification read & 15 & $13 \mathrm{q} 21.2$ \\
\hline EXOSC8 & exosome component 8 & Scaffold protein, RNA modification & 14 & $13 \mathrm{q} 13.3$ \\
\hline CREBBP & CREB binding protein & Histone modification write & 14 & $16 \mathrm{p} 13.3$ \\
\hline NCOR1 & nuclear receptor corepressor 1 & Histone modification erase cofactor & 14 & $17 \mathrm{p} 12-\mathrm{p} 11.2$ \\
\hline CUL3 & cullin 3 & Histone modification write & 13 & $2 q 36.2$ \\
\hline SP140 & SP140 nuclear body protein & Histone modification read, $\mathrm{TF}$ & 13 & $2 \mathrm{q} 37.1$ \\
\hline FOXP1 & forkhead box P1 & $\mathrm{TF}$ & 13 & $3 \mathrm{p} 13$ \\
\hline СТВР2 & C-terminal binding protein 2 & Histone modification write cofactor & 12 & $10 \mathrm{q} 26.13$ \\
\hline TRIM16 & tripartite motif containing 16 & Histone modification write & 12 & $17 \mathrm{p} 12$ \\
\hline HJURP & Holliday junction recognition protein & Histone chaperone & 11 & $2 \mathrm{q} 37.1$ \\
\hline
\end{tabular}




\subsection{Expression Changes}

Employing a twofold change cut-off, 58 genes were identified as down-regulated in UC compared to normal tissues, whereas 50 were upregulated. These genes are comprehensively listed in the Supplementary Materials (Data file S1).

String analysis [101] of downregulated genes (Figure 1A) reveals a highly linked core network containing the HATs KAT6B (MYST4, MORF) and KAT2B (PCAF), class IIA HDACs 4 and 9, and the class III (sirtuin) HDAC SIRT1, the KDM6B demethylase, as well as components of SWI/SNF, namely SMARCA2/BRM, SMARCD3/B60c, and DPF3/BAF45c. Notably, other components of the SWI/SNF multiprotein complex are upregulated (Figure 1B), hinting at a shift in its composition. Three components of the PRC1 polycomb complex are distantly linked to the core network. Two important transcription factors are highlighted by the analysis. PPARGC1A encodes a co-activator of PPAR $\gamma$, a key regulator of urothelial differentiation (see Section 1). FOXO1 downregulation has been implicated as an important factor in the progression of UC and in resistance to chemotherapy by several studies [102-104]. The present analysis suggests that its downregulation may be complemented by downregulation of co-regulators, including HAT coactivators.

The SETD7 H3K4 monomethyltransferase connects the core network with several PRDM genes. These encode proteins that likewise function as histone methylases or regulate such enzymes. PRDM proteins have been shown to exert tumor-suppressive or oncogenic functions in different cancer types (reviewed in [105]); PRDM12 and PRDM13, interestingly, are upregulated (see Figure 1B). No dedicated investigation on any family member in bladder cancer has been published, but previous bioinformatic analyses by others have also highlighted these factors [105].

String analysis of upregulated genes yields an entirely different core network, dominated by histone kinases associated with mitosis (AURKA/B, TTK, GSG2/HASPIN, PBK and others) and regulators of DNA replication and cell cycle progression (CDC6, CDK1, $C D K 3, C D K 5, T O P 2 A)$ and DNA methylation (DNMT3B, UHRF1). Like the upregulation of these factors, upregulation of chromatin assembly factors (CHAF1A/B, encoding CAF1, and the reader ATAD2) may simply reflect the increased proliferation of urothelial cancer cells compared to quiescent normal urothelium. Interestingly, CAF1 is involved particularly in the deposition of variant histones and can influence differentiation and reprogramming in this manner [106,107]. A range of genes encoding proteins involved in homologous recombination DNA repair (BRCA1/2, RAD51, UBE2T/FANC2, CHEK1, PCNA, TOP2A) is also upregulated, possibly reflecting an increased requirement in cancer cells subject to replication stress. The histone methyltransferase EZH2, a central component of the PRC2 polycomb complex, is well known to be upregulated in UC [108,109]. Likewise, upregulation of KAT2A (GCN5), with concomitant downregulation of its close paralog $K A T 2 B$, is a common finding in cancer [110]. In UC, few studies on this pair of HATs are available, but GCN5 indeed appears to contribute more to neoplastic properties of UC cells than PCAF [111]. An interesting observation is upregulation of FOXA1, a pioneer forkhead transcription factor involved in urothelial differentiation and mutated in a subset of UC [112,113].

Concordantly with their downregulation, PPARGC1A, ASXL3, SIRT1, SMARCA2, and the histone methylase genes $P R D M 5 / 6 / 16$ were also affected by mutations or homozygous deletions in at least 10 tumors. The ZNF516 gene, encoding a repressor with possible antitumor functions [97], was also subject to homozygous deletions, like the HDAC4 gene. No specific investigations on the ZNF516 repressor in bladder cancer have been published, whereas several investigations suggest that the class IIA histone deacetylase HDAC4 inhibits neoplastic properties of bladder cancer cells $[114,115]$. In comparison, the HDAC9 gene was amplified in a substantial number of cases, but its expression was downregulated on average. 
A
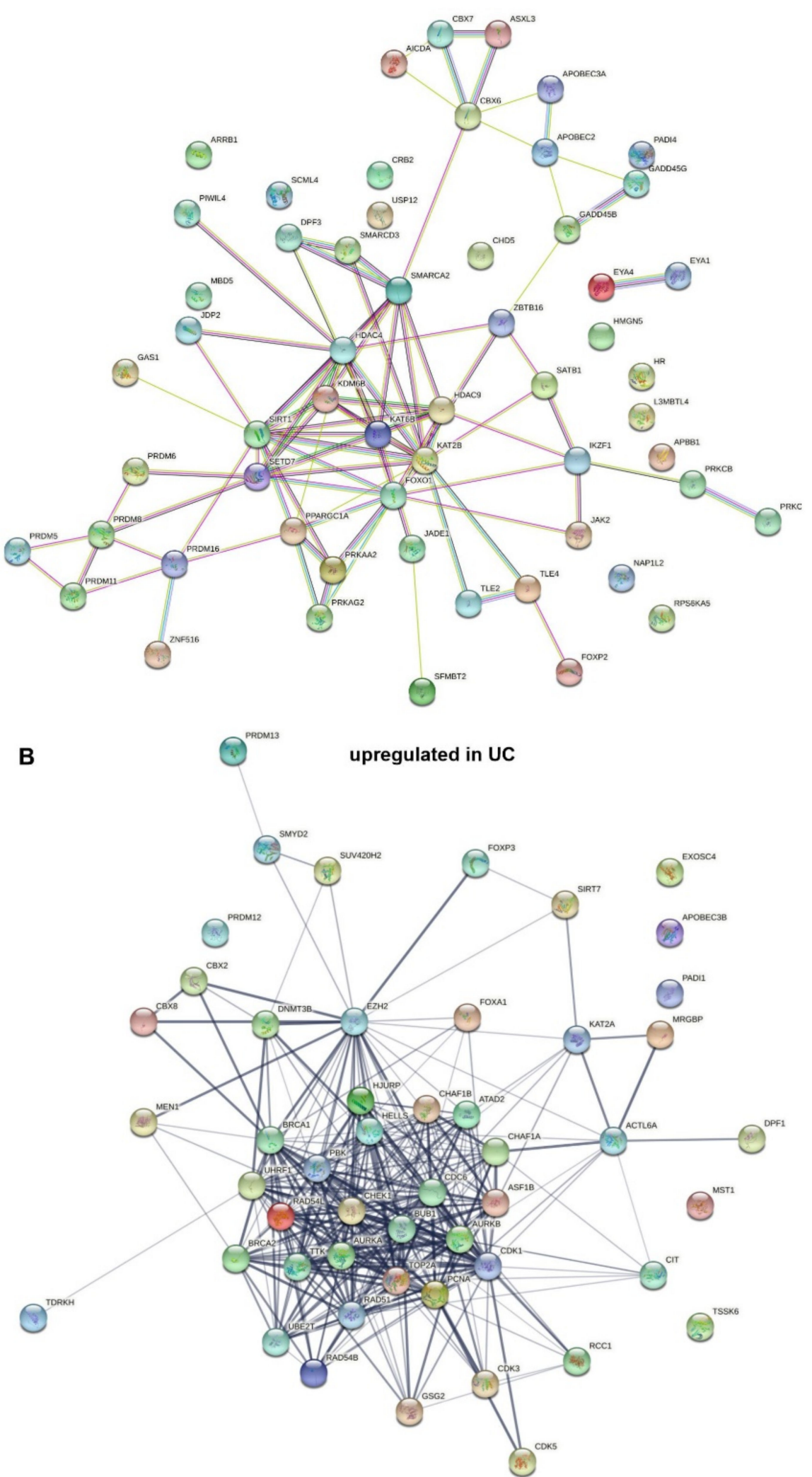

Figure 1. String analysis of chromatin regulator genes downregulated (A) and upregulated (B) in urothelial carcinoma.

Several of the upregulated genes were also subject to mutations or amplifications in at least 10 tumors. These included the genes encoding topoisomerase TOP2A, mitotic 
regulator BUB1, DNA methyltransferase DNMT3B, as well as ACTL6A encoding an actin component of chromatin remodeling complexes. ACTL6A is reported to contribute to the repression of CDKN1A/p21 ${ }^{\mathrm{CIP} 1}$ in squamous carcinomas [116], but no studies on its function in UC are available. Furthermore, $C D C 6$, encoding a chromatin licensing factor upregulated in many cancers with a presumed oncogenic function (reviewed in [117]), was mutated and amplified in many tumors. The few studies on CDC6 in bladder cancer published to date suggest a particular role in cisplatin resistance [118]. Like CDC6, ATAD2 is an E2F1 target upregulated in proliferating cells. Its product, a H4 dual acetylation reader [119], is accordingly overexpressed in many cancer types and considered to contribute to the deregulation of several signal transduction pathways (reviewed in [120]). However, for bladder cancer specifically, no studies on this important factor are available.

A few upregulated genes were-paradoxically—affected by homozygous deletions. This non-concordance may be explained by differences between individual molecular subtypes, especially in the case of FOXA1, which directs luminal differentiation. These genes in addition comprise $P B K$ (encoding a protein kinase also known as TOPK with a broad spectrum of targets, including histones [121]) and HJURP, encoding a chaperone for centromeric variant histones. Intriguingly, a sole publication on bladder cancer so far implicates HJURP in the regulation of PPAR $\gamma$ and SIRT1 [122]. A likewise single study of PBK in bladder cancer demonstrated higher expression in muscle-invasive UC by immunohistochemistry [123] in accordance with the current expression analysis.

$B R C A 1$ and $B R C A 2$ were on average upregulated (by 2.8 -fold and 3.7-fold, respectively), but a significant number of mutations and-for BRCA2-homozygous deletions was found. This likewise suggests heterogeneity among UCs in their capacity for homologous recombination repair (see Section 2.4).

\subsection{Discussion, including Literature Data}

Previous comprehensive analyses of UC genomes $[6,7,68]$ have highlighted the inactivation of proteins associated with gene activation at enhancers required for reprogramming and cell differentiation (reviewed in [124]) among chromatin regulators. These proteins include the histone methyltransferases KMT2C and KMT2D (as well as KMT2B in fewer cases), the histone demethylase KDM6A, components of the SWI/SNF complex (most often ARID1A), and the HATs CBP and p300. Importantly, these factors collaborate and interact with each other, and many are components of the same multiprotein assemblies, like the COMPASS complex, which contains alternatively KMT2C or KMT2D as its core unit and KDM6A as an associated important subunit (reviewed in [125]). Accordingly, these mutations tend to occur in a mutual exclusive manner in UC, suggesting that they lead to similar consequences [79]. Importantly, almost each case of UC carries at least one mutation in one of these genes. Of note, while most mutations in these genes are predicted or demonstrated to be deleterious, it is not established for each of the genes whether both alleles are regularly inactivated in a manner expected for 'classical' tumor suppressors (see discussion in [79]).

The group of factors regularly mutated in UC can be considered as trithorax-like activators that counteract the activity of polycomb repressor complexes during development and cell differentiation (reviewed in [126,127]). Basically, two polycomb complexes, PRC1 and PRC2, are distinguished, which can each vary in composition. The present analysis confirms again that EZH2, one of two alternative catalytic subunits of the polycomb repressor complex PRC2, is upregulated in many UCs. Regarding the PRC1 complex, most studies in UC have focused on the BMI1 subunit, which is implicated in promoting invasion by repression of microRNA genes [128] and as a possible stem cell factor. Other PRC1 components are less well studied.

Polycomb complexes are established as key regulators of epidermal differentiation [129]. PRC1 and PRC2 have different roles but cooperate in epidermal precursor cells. PRC2 maintains proliferation of precursor cells, preventing premature differentiation by repressing epidermal specific genes. PRC1 represses alternative lineage choices. During differentia- 
tion, however, a differently composed PRC1 complex promotes the expression of epidermal genes, especially for adhesion factors [130]. As our analysis revealed downregulation of several PRC1-related genes, it could be interesting to investigate whether the composition of the PRC1 complex changes in UC.

Gene repression by PRC1 is partly mediated via histone H2A mono-ubiquitination, resulting in the H2AK119ub1 modification. This modification is removed by a protein complex containing the deubiquitinase BAP1 as the central unit. Inactivating mutations of $\mathrm{BAP} 1$ and deletion of its gene at $3 \mathrm{p}$ are prominent in renal cell carcinoma [131] but have also been described to co-occur with KDM6A mutations in UC [132]. Our analysis revealed significant downregulation and frequent mutations of ASXL3. ASXL proteins in general serve to link chromatin and chromatin-modifying protein complexes. ASXL3 is less well studied than its paralogs but was shown to promote BAP1 binding to its histone substrate like its paralogs [133]. Its downregulation in UC could therefore ultimately contribute to gene repression.

As suggested by its name, BAP1 (BRCA1-associated protein 1) influences also DNA repair (reviewed in [134]), especially through BRCA1. Our present analysis unexpectedly revealed considerable and significant upregulation of both $B R C A 1$ and $B R C A 2$ expression across UC, but also relatively frequent mutations in both genes and even homozygous deletions of $B R C A 2$. Inactivation of homologous recombination repair is thought to occur relatively infrequently in bladder cancer and biallelic inactivation of $B R C A 1$ or $B R C A 2$ is rare. Mutational signatures reflecting homologous recombination repair deficiency ('BRCAness') are found in fewer than 10\% of all invasive UCs [135]. The present analysis suggests that, instead, upregulation of $B R C A 1$ and $B R C A 2$ is prevalent, potentially in a different subset of cancers. In particular, loss of KMT2C in UC cells was shown to decrease the expression of DNA repair genes. Moreover, $\mathrm{Kmt} 2 \mathrm{c}$ knockout in mice induced ureter tumors with a high level of DNA double-strand breaks [136]. This genomic instability was ascribed to a co-activator function of the COMPASS (a.k.a. ASCOM) complex for TP53. UC cells with KMT2C mutations were moreover more sensitive to PARP inhibitors like olaparib [137]. However, PARP inhibitors, which exploit deficiencies in homologous recombination repair in tumor cells, have so far shown little benefit as a monotherapy for bladder cancer in clinical trials [138]. As more drugs targeting homologous recombination repair deficiency are becoming available, the state of homologous recombination repair in UC clearly deserves further clarification.

Another interesting factor highlighted by our analysis is the class III histone deacetylase SIRT1. SIRT1 deacetylates H4 but also many non-histone proteins, including TP53, as well as other proteins involved in DNA repair and checkpoints. In some cancer types, SIRT1 is upregulated and therefore considered as a target for specific inhibitors [139]. Pharmacological activators are also available (reviewed in [140]) and may be applied in those cancer types where SIRT1 is instead downregulated. The present analysis revealed downregulation, mutation, and homozygous deletion in many UCs, suggesting that they belong to the latter type. According, a sirtuin activator inhibited bladder cancer growth in organoids [141]. Moreover, SIRT1 was described to interact in a feedback loop with $\operatorname{PPAR} \gamma[142]$.

\section{Consequences of Chromatin Regulator Alterations in Urothelial Carcinoma}

\subsection{Differentiation, Plasticity, and Immune Responses}

The trithorax-like factors regularly inactivated by mutations in UC are known to be involved in the differentiation of many cell lineages (reviewed in [44,143]). One would therefore presume that their inactivation in UC would lead to a block in differentiation. However, many UCs present with markers of differentiated urothelial cells, especially all luminal subtypes. Moreover, in the TCGA study, genomic alterations of trithorax-like genes, SWI/SNF genes, and cohesin complex genes were essentially equally frequent across all molecular subtypes (see Figure 3 in ref. [7]). 
The luminal-papillary subtype expresses a particularly broad range of urothelial differentiation markers and is characterized especially by frequent KDM6A loss of function and FGFR3 oncogenic mutations. Intriguingly, active FGFR3 leads to repression of many enhancers of luminal urothelial genes that are normally bound and activated by KDM6A [144]. This antagonism explains why the two genetic alterations collaborate in tumorigenesis but not why the ensuing tumors prominently express luminal genes.

The function of the PRC2 catalytic subunit EZH2, a direct antagonist of KDM6A with respect to $\mathrm{H} 3 \mathrm{~K} 27$ methylation, is intriguing in this context. As in epidermal differentiation [129], EZH2 supports the proliferation of basal cells, while limiting the differentiation of intermediate and superficial cells in the normal murine urothelium. However, its expression prevents squamous differentiation and ectopic expression of Krt14 in mouse models [145]. Global comparisons of epigenetic modifications between human bladder cancer cell lines and normal urothelial cells moreover suggest that EZH2 is involved in regulating the balance between normal differentiation and malignant transformation. Trimethylation at H3K27 was located in a more focal manner at transcriptional start sites in normal cells, whereas the modification was distributed more evenly across gene sequences [146]. This redistribution may reflect the frequent upregulation of EZH2 [109] and loss of the KDM6A demethylase in many UCs. Accordingly, the KDM6A paralog KDM6B/JMJD3 is known to contribute to differentiation of cultured primary keratinocytes [147]. In primary urothelial and HBLAK cells, knockdown of KDM6A affected the balance between KRT14positive stem cells and KRT5-positive basal cells but had only limited effects on further differentiation of luminal cells [148].

Other luminal subtypes appear to be supported by lineage-specific oncogenes, i.e., transcription factors involved in urothelial differentiation that are activated by mutations, especially PPAR $\gamma$ and its heterodimerization partner $\operatorname{RXR} \alpha$ in the luminal unstable and ELF3 in the luminal unspecified subtype. Mutations in FOXA1 may contribute. However, despite activation of urothelial differentiation, these tumor cells do not exit the cell cycle. This might be explained partly by the loss of TP53 and especially RB1 inactivation, which prevent cell cycle exit and terminal differentiation. Loss of cell cycle control in general and RB1 activity specifically may account for the overexpression of many genes involved in DNA replication and cell cycle progression as revealed by our analysis (Figure 1B). Moreover, oncogenic PPAR $\gamma$ may activate additional growth signals, such as the SHH pathway [43]. It is unclear how loss of the trithorax-like factors contributes to the phenotype of these other luminal subtypes. Notably, lineage-specific oncogenes in other cancers require functional co-activators. For instance, KDM6A, KMT2C, and the SWI/SNF complex support estrogen receptor activity in luminal breast cancers, although these chromatin regulators may be inactivated during further progression and development of resistance to anti-estrogenic treatments (reviewed in [149]).

In contrast, the BASQ and neuronal-like transdifferentiated UC subtypes do not express markers of urothelial differentiation. Whereas FOXA1, GATA3, and PPAR $\gamma$ support expression of luminal subtype-specific genes, TP63, STAT3, and TFAP2 are main determinators of the basal cell phenotype [150]. Accordingly, transcription factors directing luminal differentiation are often repressed in BASQ cancers [151,152]. The retention of a basal state in BASQ UC could be explained by a predominance of PRC2 polycomb activity if trithorax-like factors driving differentiation are mutated. PRC2 would then maintain a proliferative basal cell precursor phenotype, as demonstrated in epidermal cells [129]. Notably, the histone demethylase KDM1A/LSD1, with dual specificity for H3K4 and H3K9, likewise represses key transcription factors for keratinocyte fate and differentiation [153]. Inhibition of LSD1 conversely induces terminal epidermal differentiation via NOTCH3, ZNF750, and the Grainyhead transcription factors GRHL1 and GRHL3 [154]. The function of KDM1A in urothelial differentiation and UC is however poorly understood [155]. In any case, enhanced EGFR signaling may provide one stimulus for the continuous proliferation of the BASQ subtype cells $[39,156]$, particularly in the absence of functional TP53 and RB1. 
Another characteristic of the BASQ subtype is its plasticity, which results in more or less extensive squamous differentiation. Plasticity with loss of lineage fidelity is a frequent phenomenon in epithelial cells proliferating during wound healing and proliferation [157]. It is observed even in cultured normal urothelial cells, which can be stimulated to undergo either squamous or urothelial differentiation, depending on the stimulus [34,158]. It further manifests as benign squamous metaplasia in urinary bladders, often associated with chronic inflammation [159]. As in other instances of squamous metaplasia, in the bladder, it may constitute an adaptive response to protect epithelia from noxious conditions [160]. In UC, clearly, loss of the ability for urothelial differentiation does not preclude aberrant differentiation to a squamous phenotype. Again, loss of TP53 and RB1 function appears to favor not only continuous proliferation but also metaplasia.

Loss of these two regulators is also observed in rare sarcomatoid bladder cancers, [161] which are thought to arise from basal cells. It is moreover fundamental for the development of many cancers with a neuroendocrine phenotype, including some androgen-independent prostate cancers and small-cell lung carcinomas [162,163], and evidently neuronal-like UC [39]. To which extent inactivation of trithorax-like chromatin regulators contributes to this type of plasticity is currently not fully understood. Our present analysis (see Section 2) suggests alterations in Co-REST components to be relevant. A prominent physiological function of this co-repressor complex is suppression of non-neuronal lineages in neuronal cells, but in cancers it may exert a number of alternative functions. Its functionality in neuronal-like UC would therefore be of great interest.

Finally, the molecular subtypes differ also in the type and extent of immune cell infiltration. Immune cell infiltration is most pronounced in the luminal-unspecified and the BASQ subtypes [39], whereas the luminal-papillary subtype appears to actively suppress anti-tumor immunity $[151,164]$. Accumulating evidence implicates chromatin regulators in the regulation of immune responses in UC [165-167] and epigenetic drugs, i.e., inhibitors of histone and DNA modifying enzymes, may therefore be used to re-sensitize UC to immunotherapies (reviewed in [168-171]).

\subsection{A Model of Urothelial Carcinoma Development}

Two recent papers [172,173] have characterized mutations in micro-dissected morphologically normal urothelium obtained from transplant donors or from cystectomies for urothelial carcinoma. Both research groups detected many mutations in normal urothelium, although their frequency was lower than in muscle-invasive UC. Mutant cells were found to expand clonally in normal urothelium, with clones occupying up to several square $\mathrm{mm}$. Some clones in the normal urothelium of UC patients shared mutations with the tumors. In contrast, synchronous carcinoma in situ (CIS) were clearly related to the main tumor, sharing several mutations but having further evolved along a separate trajectory. Thus, the normal urothelium of middle-aged and elderly persons contains clones of cells with mutant genomes. Importantly, these clones likely account for the often-multifocal emergence of urothelial tumors and may underlie their pronounced tendency to recur.

Whereas point mutations were frequently observed, few of the cell clones expanding in the normal urothelium contained gene copy number changes or chromosomal abnormalities that are prominent in high-grade UC and especially CIS. If at all, entire chromosomes or chromosome arms were lost or gained in normal urothelium. This observation further links chromosomal instability to progression towards invasive carcinoma in urothelial carcinogenesis [4].

Intriguingly, in both studies [172,173], chromatin regulator genes were the most frequently mutated functional class of genes, especially KMT2D, KDM6A, and ARID1A, as well as EP300, STAG2, and CREBBP. In contrast, not the activating FGFR3 mutations observed in most papillary UCs, nor mutations in TP53 typical of muscle-invasive UC, nor hTERT mutations found in $\approx 80 \%$ of UCs across all stages were detected at significant frequencies. These observations suggest that mutations in chromatin regulators occur at an early step of urothelial carcinogenesis and possibly represent an initial—truncal—event. 
The observation that chromatin regulator mutations are found across all stages and molecular subtypes of UC supports this assumption. Mutations activating proliferative signal transduction pathways and cell cycling, inactivating cellular checkpoints and preventing senescence, would then lead to actual tumor development (Figure 2).

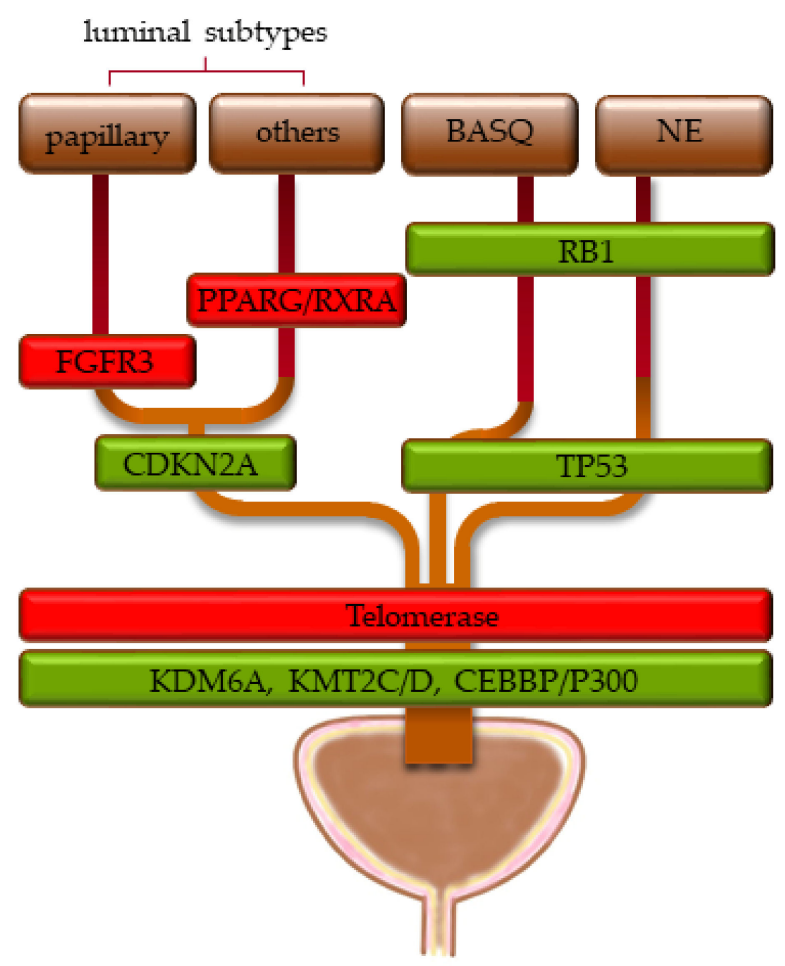

Figure 2. Proposed sequence of genomic changes in urothelial carcinogenesis, proceeding from bottom to top. Green boxes indicate loss of function, red boxes indicate oncogenic activation. The width of the boxes indicates the approximate distribution of the genomic alterations across the molecular subtypes (see Section 1.2 for their definitions).

Analogous observations have been made in other tissues (reviewed in [174]). The phenomenon is best characterized in the hematopoietic system, known as clonal hematopoiesis. With increasing age, stem cells in the bone marrow acquire mutations, most often in epigenetic regulator genes (in this case, DNMT3A, TET2, ASXL1). These mutant stem cells expand and replace normal stem cells. While the hematopoietic system remains largely functional, clonal hematopoiesis increases the risk for leukemia. The transformation to leukemia requires additional mutations that activate oncogenes (like FLT3 or RAS) or inactivate tumor suppressors (like TP53 or CEBPA) [175]. Interestingly, specifically $K M T 2 C$ inactivating mutations have been shown to enhance the self-renewal capacity of hematopoietic stem cells [176].

Accordingly, there is no evidence that the mutations in chromatin regulator genes detected in normal urothelium severely affect its functionality or grossly impede its differentiation [172,173]. Moreover, chromatin regulator mutations are found in all molecular subtypes of UC, not only in subtypes like BASQ and neuronal-like lacking markers of urothelial differentiation. This suggests that their primary effect is not to completely block urothelial differentiation, despite the well-established requirement for trithorax-like factors in reprogramming of enhancers and gene expression during development and cell differentiation. Rather, chromatin regulator mutations may enhance the self-renewal ability of urothelial precursor cells, favoring their clonal expansion. In support of this idea, we observed that knockdown of KDM6A in primary urothelial cell cultures and the normal urothelial cell line HBLAK, which comprise basal cells and KRT14-expressing stem cells, increased the proportion of cells expressing KRT14 [148]. Mutations inactivating KDM6A in normal urothelium may therefore augment the capacity of urothelial KRT14-expressing 
precursor cells for self-renewal, allowing them to gradually colonize the tissue at the expense of non-mutant urothelial precursors. Mutations inactivating other chromatin regulators like KMT2D may act in a similar fashion. Evidently, more experimental evidence is required to decide whether this hypothesis applies to urothelial carcinogenesis.

Several questions in particular need to be addressed to validate and clarify this hypothesis. First, by which mechanisms does inactivation of chromatin regulators enhance self-renewal of urothelial stem cells? Second, in which respect do KRT14-positive stem cells with mutant chromatin regulators differ from normal ones? While not grossly disturbed, to which extent is their differentiation ability impeded in detail? Third, do all chromatin regulator mutations favor carcinogenesis to the same extent? Fourth, do they favor the development of specific molecular subtypes? For instance, KDM6A mutations appear to be particularly frequent in the luminal-papillary subtype, both in muscle-invasive UC and non-invasive urothelial tumors, and are often accompanied by FGFR3 mutations. The study by Barrows et al. [144] provides a partial explanation for this association. Similarly, the oncogenic function of mutant RXRA/PPAR $\gamma$ in organoids depended on inactivation of KDM6A as well as TP53 [177]. Moreover, PPAR $\gamma$ was recently demonstrated to induce tumors in basal precursors only following injury, again suggesting that its oncogenic action depends on an altered epigenetic state [152].

The ideas on the function of chromatin regulator mutations in urothelial carcinogenesis outlined above have important implications for targeted therapeutic approaches. Targeted therapies have been relatively unsuccessful in UC, with the recent exception of FGFR inhibitors in the papillary-luminal subtype [41,42]. On this background, the high prevalence of mutations in chromatin regulators provides a further rationale to explore epigenetic drugs, i.e., compounds that influence histone and DNA modifications $[178,179]$. Ideally, these drugs would reverse the deficits resulting from chromatin regulator inactivation in UC. Appropriate treatments could limit cellular plasticity and exhaust self-renewing cancer cell populations by forcing them into terminal differentiation [180]. However, if inactivation of chromatin regulators occurs at a very early stage of carcinogenesis, it may only set the stage for subsequent transformation and might not necessarily be required for growth and survival of the actual cancers. This issue clearly calls for deeper investigation. The findings so far suggest that restoration of KDM6A function does affect proliferation of UC cells but usually only over time $[132,148,181,182]$. These delayed effects could be explained by decreased self-renewal ability of tumor stem cells.

While restoration of its function might come too late to suppress tumor growth, lack of a chromatin regulator may sensitize cancers to the inhibition of different chromatin regulators or other processes that are essential for tumor growth, i.e., it may generate synthetic lethality. For instance, ARID1A-deficient tumors are particularly sensitive to inactivation of its paralog ARID1B, which leads to dissociation of the remaining SWI/SNF complexes with alternative composition $[183,184]$. In UC, specifically, KDM6A inactivation appears to sensitize tumors towards inhibitors of its antagonist, the histone methyltransferase EZH2 [182]. Similarly, since KMT2C mutations diminish the expression of genes required for homologous recombination DNA repair, they may sensitize deficient UC cells to PARP inhibitors like olaparib [137]. The latter example highlights the point that mutations in chromatin regulators might not only affect cell differentiation but also other cellular processes, including DNA repair, metabolism, and cell adhesion [182,185-189]. Moreover, with an increasing repertoire of immunotherapies, the emerging effects of chromatin regulator deficiencies on anti-tumor immune responses [165-167,190,191] could provide new approaches for targeted therapy in UC.

\section{Conclusions-Prospects}

In this review, we re-analyzed data from the TCGA comprehensive investigation of genetic alterations in urothelial carcinoma with respect to chromatin regulators and summarized the state of the literature on their functions in this cancer type. Our data analysis revealed additional candidate factors and relations that merit further investigation 
in urothelial carcinoma to improve the understanding of pathogenetic mechanisms in this cancer. The literature analysis led us to propose a hypothesis on the biological function of the most frequently inactivated - trithorax-like - chromatin regulators in urothelial carcinogenesis. Throughout these analyses, we could not help noting that despite much recent progress, bladder cancer remains under-researched. In particular, mechanistic studies addressing the molecular and cellular consequences of chromatin regulator alterations, specifically in urothelial cells, are sparse. Hopefully, the current review will not only alert to that fact, but provide information and ideas that help to ameliorate these deficiencies.

Supplementary Materials: The following are available online at https: / www.mdpi.com/article/ 10.3390/cancers13236040/s1, Data file S1: Complete data for genomic alterations and significant expression changes of chromatin regulators.

Author Contributions: Conceptualization, formal analysis, investigation, data curation, writingoriginal draft preparation, review and editing, M.J.H. and W.A.S. All authors have read and agreed to the published version of the manuscript.

Funding: The research of M.J.H. was funded by the Deutsche Forschungsgemeinschaft (DFG), grant number HO6448/2-1.

Data Availability Statement: The analyzed data are publicly available from the Morpheus database or Supplementary Materials of ref. [7]. All results of data analyses presented in this study are available in Supplementary Data File 1.

Conflicts of Interest: The authors declare no conflict of interest.

\section{References}

1. Ferlay, J.; Colombet, M.; Soerjomataram, I.; Mathers, C.; Parkin, D.M.; Pineros, M.; Znaor, A.; Bray, F. Estimating the global cancer incidence and mortality in 2018: GLOBOCAN sources and methods. Int. J. Cancer 2019, 144, 1941-1953. [CrossRef] [PubMed]

2. Kiemeney, L.A.; Witjes, J.A.; Verbeek, A.L.; Heijbroek, R.P.; Debruyne, F.M. The clinical epidemiology of superficial bladder cancer. Dutch South-East Cooperative Urological Group. Br. J. Cancer 1993, 67, 806-812. [CrossRef] [PubMed]

3. Cheng, L.; Zhang, S.; MacLennan, G.T.; Williamson, S.R.; Lopez-Beltran, A.; Montironi, R. Bladder cancer: Translating molecular genetic insights into clinical practice. Hum. Pathol. 2011, 42, 455-481. [CrossRef] [PubMed]

4. Knowles, M.A.; Hurst, C.D. Molecular biology of bladder cancer: New insights into pathogenesis and clinical diversity. Nat. Rev. Cancer 2015, 15, 25-41. [CrossRef]

5. Tran, L.; Xiao, J.F.; Agarwal, N.; Duex, J.E.; Theodorescu, D. Advances in bladder cancer biology and therapy. Nat. Rev. Cancer 2021, 21, 104-121. [CrossRef]

6. Gui, Y.; Guo, G.; Huang, Y.; Hu, X.; Tang, A.; Gao, S.; Wu, R.; Chen, C.; Li, X.; Zhou, L.; et al. Frequent mutations of chromatin remodeling genes in transitional cell carcinoma of the bladder. Nat. Genet. 2011, 43, 875-878. [CrossRef]

7. Robertson, A.G.; Kim, J.; Al-Ahmadie, H.; Bellmunt, J.; Guo, G.; Cherniack, A.D.; Hinoue, T.; Laird, P.W.; Hoadley, K.A.; Akbani, R.; et al. Comprehensive Molecular Characterization of Muscle-Invasive Bladder Cancer. Cell 2017, 171, 540-556. [CrossRef]

8. Fujii, Y.; Sato, Y.; Suzuki, H.; Kakiuchi, N.; Yoshizato, T.; Lenis, A.T.; Maekawa, S.; Yokoyama, A.; Takeuchi, Y.; Inoue, Y.; et al. Molecular classification and diagnostics of upper urinary tract urothelial carcinoma. Cancer Cell 2021, 39, 793-809. [CrossRef] [PubMed]

9. Sfakianos, J.P.; Gul, Z.; Shariat, S.F.; Matin, S.F.; Daneshmand, S.; Plimack, E.; Lerner, S.; Roupret, M.; Pal, S. Genetic Differences between Bladder and Upper Urinary Tract Carcinoma: Implications for Therapy. Eur. Urol. Oncol. 2021, 4, 170-179. [CrossRef] [PubMed]

10. Balsara, Z.R.; Li, X. Sleeping beauty: Awakening urothelium from its slumber. Am. J. Physiol. Renal. Physiol. 2017, 312 , F732-F743. [CrossRef] [PubMed]

11. Jost, S.P.; Gosling, J.A.; Dixon, J.S. The morphology of normal human bladder urothelium. J. Anat. 1989, 167, 103-115. [PubMed]

12. Wang, C.; Ross, W.T.; Mysorekar, I.U. Urothelial generation and regeneration in development, injury, and cancer. Dev. Dyn. 2017, 246, 336-343. [CrossRef] [PubMed]

13. Birder, L.; Andersson, K.E. Urothelial signaling. Physiol. Rev. 2013, 93, 653-680. [CrossRef] [PubMed]

14. Papafotiou, G.; Paraskevopoulou, V.; Vasilaki, E.; Kanaki, Z.; Paschalidis, N.; Klinakis, A. KRT14 marks a subpopulation of bladder basal cells with pivotal role in regeneration and tumorigenesis. Nat. Commun. 2016, 7, 11914. [CrossRef] [PubMed]

15. Kurzrock, E.A.; Lieu, D.K.; Degraffenried, L.A.; Chan, C.W.; Isseroff, R.R. Label-retaining cells of the bladder: Candidate urothelial stem cells. Am. J. Physiol. Renal. Physiol. 2008, 294, F1415-F1421. [CrossRef]

16. Gaisa, N.T.; Graham, T.A.; McDonald, S.A.; Canadillas-Lopez, S.; Poulsom, R.; Heidenreich, A.; Jakse, G.; Tadrous, P.J.; Knuechel, R.; Wright, N.A. The human urothelium consists of multiple clonal units, each maintained by a stem cell. J. Pathol. 2011, 225, 163-171. [CrossRef] [PubMed] 
17. Colopy, S.A.; Bjorling, D.E.; Mulligan, W.A.; Bushman, W. A Population of Progenitor Cells in the Basal and Intermediate Layers of the Murine Bladder Urothelium Contributes to Urothelial Development and Regeneration. Dev. Dynam. 2014, 243, 988-998. [CrossRef] [PubMed]

18. Gandhi, D.; Molotkov, A.; Batourina, E.; Schneider, K.; Dan, H.B.; Reiley, M.; Laufer, E.; Metzger, D.; Liang, F.X.; Liao, Y.; et al. Retinoid Signaling in Progenitors Controls Specification and Regeneration of the Urothelium. Dev. Cell 2013, 26, 469-482. [CrossRef] [PubMed]

19. Schafer, F.M.; Algarrahi, K.; Savarino, A.; Yang, X.H.; Seager, C.; Franck, D.; Costa, K.; Liu, S.S.; Logvinenko, T.; Adam, R.; et al. Mode of Surgical Injury Influences the Source of Urothelial Progenitors during Bladder Defect Repair. Stem Cell Rep. 2017, 9, 2005-2017. [CrossRef] [PubMed]

20. Wu, X.R.; Kong, X.P.; Pellicer, A.; Kreibich, G.; Sun, T.T. Uroplakins in urothelial biology, function, and disease. Kidney Int. 2009, 75, 1153-1165. [CrossRef] [PubMed]

21. Shin, K.; Lee, J.; Guo, N.; Kim, J.; Lim, A.; Qu, L.; Mysorekar, I.U.; Beachy, P.A. Hedgehog/Wnt feedback supports regenerative proliferation of epithelial stem cells in bladder. Nature 2011, 472, 110-114. [CrossRef] [PubMed]

22. Shin, K.; Lim, A.; Zhao, C.; Sahoo, D.; Pan, Y.; Spiekerkoetter, E.; Liao, J.C.; Beachy, P.A. Hedgehog signaling restrains bladder cancer progression by eliciting stromal production of urothelial differentiation factors. Cancer Cell 2014, 26, 521-533. [CrossRef] [PubMed]

23. Fishwick, C.; Higgins, J.; Percival-Alwyn, L.; Hustler, A.; Pearson, J.; Bastkowski, S.; Moxon, S.; Swarbreck, D.; Greenman, C.D.; Southgate, J. Heterarchy of transcription factors driving basal and luminal cell phenotypes in human urothelium. Cell Death Differ. 2017, 24, 809-818. [CrossRef]

24. Yamashita, H.; Amponsa, V.O.; Warrick, J.I.; Zheng, Z.; Clark, P.E.; Raman, J.D.; Wu, X.R.; Mendelsohn, C.; DeGraff, D.J. On a FOX hunt: Functions of FOX transcriptional regulators in bladder cancer. Nat. Rev. Urol. 2017, 14, 98-106. [CrossRef] [PubMed]

25. Gatti, V.; Fierro, C.; Annicchiarico-Petruzzelli, M.; Melino, G.; Peschiaroli, A. DeltaNp63 in squamous cell carcinoma: Defining the oncogenic routes affecting epigenetic landscape and tumour microenvironment. Mol. Oncol. 2019, 13, 981-1001. [CrossRef]

26. Boxer, L.D.; Barajas, B.; Tao, S.; Zhang, J.; Khavari, P.A. ZNF750 interacts with KLF4 and RCOR1, KDM1A, and CTBP1/2 chromatin regulators to repress epidermal progenitor genes and induce differentiation genes. Genes Dev. 2014, 28, 2013-2026. [CrossRef] [PubMed]

27. Sen, G.L.; Boxer, L.D.; Webster, D.E.; Bussat, R.T.; Qu, K.; Zarnegar, B.J.; Johnston, D.; Siprashvili, Z.; Khavari, P.A. ZNF750 is a p63 target gene that induces KLF4 to drive terminal epidermal differentiation. Dev. Cell 2012, 22, 669-677. [CrossRef]

28. Hopkin, A.S.; Gordon, W.; Klein, R.H.; Espitia, F.; Daily, K.; Zeller, M.; Baldi, P.; Andersen, B. GRHL3/GET1 and trithorax group members collaborate to activate the epidermal progenitor differentiation program. PLoS Genet. 2012, 8, e1002829. [CrossRef]

29. Hustler, A.; Eardley, I.; Hinley, J.; Pearson, J.; Wezel, F.; Radvanyi, F.; Baker, S.C.; Southgate, J. Differential transcription factor expression by human epithelial cells of buccal and urothelial derivation. Exp. Cell Res. 2018, 369, 284-294. [CrossRef] [PubMed]

30. Liu, C.; Tate, T.; Batourina, E.; Truschel, S.T.; Potter, S.; Adam, M.; Xiang, T.; Picard, M.; Reiley, M.; Schneider, K.; et al. Pparg promotes differentiation and regulates mitochondrial gene expression in bladder epithelial cells. Nat. Commun. 2019, 10, 4589. [CrossRef]

31. Bell, S.M.; Zhang, L.; Mendell, A.; Xu, Y.; Haitchi, H.M.; Lessard, J.L.; Whitsett, J.A. Kruppel-like factor 5 is required for formation and differentiation of the bladder urothelium. Dev. Biol. 2011, 358, 79-90. [CrossRef] [PubMed]

32. Bock, M.; Hinley, J.; Schmitt, C.; Wahlicht, T.; Kramer, S.; Southgate, J. Identification of ELF3 as an early transcriptional regulator of human urothelium. Dev. Biol. 2014, 386, 321-330. [CrossRef] [PubMed]

33. Yu, Z.; Mannik, J.; Soto, A.; Lin, K.K.; Andersen, B. The epidermal differentiation-associated Grainyhead gene Get1/Grhl3 also regulates urothelial differentiation. EMBO J. 2009, 28, 1890-1903. [CrossRef] [PubMed]

34. Southgate, J.; Hutton, K.A.; Thomas, D.F.; Trejdosiewicz, L.K. Normal human urothelial cells in vitro: Proliferation and induction of stratification. Lab. Investig. 1994, 71, 583-594. [PubMed]

35. Varley, C.; Hill, G.; Pellegrin, S.; Shaw, N.J.; Selby, P.J.; Trejdosiewicz, L.K.; Southgate, J. Autocrine regulation of human urothelial cell proliferation and migration during regenerative responses in vitro. Exp. Cell Res. 2005, 306, 216-229. [CrossRef]

36. Varley, C.L.; Southgate, J. Effects of PPAR agonists on proliferation and differentiation in human urothelium. Exp. Toxicol. Pathol. 2008, 60, 435-441. [CrossRef]

37. Barton, C.E.; Johnson, K.N.; Mays, D.M.; Boehnke, K.; Shyr, Y.; Boukamp, P.; Pietenpol, J.A. Novel p63 target genes involved in paracrine signaling and keratinocyte differentiation. Cell Death Dis. 2010, 1, e74. [CrossRef] [PubMed]

38. Hoffmann, M.J.; Koutsogiannouli, E.; Skowron, M.A.; Pinkerneil, M.; Niegisch, G.; Brandt, A.; Stepanow, S.; Rieder, H.; Schulz, W.A. The New Immortalized Uroepithelial Cell Line HBLAK Contains Defined Genetic Aberrations Typical of Early Stage Urothelial Tumors. Bladder Cancer 2016, 2, 449-463. [CrossRef]

39. Kamoun, A.; de Reynies, A.; Allory, Y.; Sjodahl, G.; Robertson, A.G.; Seiler, R.; Hoadley, K.A.; Groeneveld, C.S.; Al-Ahmadie, H.; Choi, W.; et al. A Consensus Molecular Classification of Muscle-invasive Bladder Cancer. Eur. Urol. 2020, 77, 420-433. [CrossRef] [PubMed]

40. Hurst, C.D.; Alder, O.; Platt, F.M.; Droop, A.; Stead, L.F.; Burns, J.E.; Burghel, G.J.; Jain, S.; Klimczak, L.J.; Lindsay, H.; et al. Genomic Subtypes of Non-invasive Bladder Cancer with Distinct Metabolic Profile and Female Gender Bias in KDM6A Mutation Frequency. Cancer Cell 2017, 32, 701-715. [CrossRef] [PubMed] 
41. Montazeri, K.; Bellmunt, J. Erdafitinib for the treatment of metastatic bladder cancer. Expert Rev. Clin. Pharmacol. 2020, 13, 1-6. [CrossRef]

42. Van Rhijn, B.W.G.; Mertens, L.S.; Mayr, R.; Bostrom, P.J.; Real, F.X.; Zwarthoff, E.C.; Boormans, J.L.; Abas, C.; van Leenders, G.; Gotz, S.; et al. FGFR3 Mutation Status and FGFR3 Expression in a Large Bladder Cancer Cohort Treated by Radical Cystectomy: Implications for Anti-FGFR3 Treatment? Eur. Urol. 2020, 78, 682-687. [CrossRef]

43. Sanchez, D.J.; Missiaen, R.; Skuli, N.; Steger, D.J.; Simon, M.C. Cell-Intrinsic Tumorigenic Functions of PPARgamma in Bladder Urothelial Carcinoma. Mol. Cancer Res. 2021, 19, 598-611. [CrossRef] [PubMed]

44. Chen, T.; Dent, S.Y. Chromatin modifiers and remodellers: Regulators of cellular differentiation. Nat. Rev. Genet. 2014, 15, 93-106. [CrossRef] [PubMed]

45. Feinberg, A.P. Phenotypic plasticity and the epigenetics of human disease. Nature 2007, 447, 433-440. [CrossRef]

46. Klemm, S.L.; Shipony, Z.; Greenleaf, W.J. Chromatin accessibility and the regulatory epigenome. Nat. Rev. Genet. 2019, 20, 207-220. [CrossRef]

47. Roostaee, A.; Benoit, Y.D.; Boudjadi, S.; Beaulieu, J.F. Epigenetics in Intestinal Epithelial Cell Renewal. J. Cell. Physiol. 2016, 231, 2361-2367. [CrossRef] [PubMed]

48. Plass, C.; Pfister, S.M.; Lindroth, A.M.; Bogatyrova, O.; Claus, R.; Lichter, P. Mutations in regulators of the epigenome and their connections to global chromatin patterns in cancer. Nat. Rev. Genet. 2013, 14, 765-780. [CrossRef] [PubMed]

49. Zhu, H.; Wang, G.; Qian, J. Transcription factors as readers and effectors of DNA methylation. Nat. Rev. Genet. 2016, 17, 551-565. [CrossRef] [PubMed]

50. Kandimalla, R.; van Tilborg, A.A.; Kompier, L.C.; Stumpel, D.J.; Stam, R.W.; Bangma, C.H.; Zwarthoff, E.C. Genome-wide analysis of CpG island methylation in bladder cancer identified TBX2, TBX3, GATA2, and ZIC4 as pTa-specific prognostic markers. Eur. Urol. 2012, 61, 1245-1256. [CrossRef] [PubMed]

51. Mancini, M.; Righetto, M.; Zumerle, S.; Montopoli, M.; Zattoni, F. The Bladder EpiCheck Test as a Non-Invasive Tool Based on the Identification of DNA Methylation in Bladder Cancer Cells in the Urine: A Review of Published Evidence. Int. J. Mol. Sci. 2020, 21, 6542. [CrossRef] [PubMed]

52. Nunes, S.P.; Henrique, R.; Jeronimo, C.; Paramio, J.M. DNA Methylation as a Therapeutic Target for Bladder Cancer. Cells 2020, 9 , 1850. [CrossRef] [PubMed]

53. Piatti, P.; Chew, Y.C.; Suwoto, M.; Yamada, T.; Jara, B.; Jia, X.Y.; Guo, W.; Ghodoussipour, S.; Daneshmand, S.; Ahmadi, H.; et al. Clinical evaluation of Bladder CARE, a new epigenetic test for bladder cancer detection in urine samples. Clin. Epigenetics 2021, 13, 84. [CrossRef] [PubMed]

54. Schulz, W.A.; Goering, W. DNA methylation in urothelial carcinoma. Epigenomics 2016, 8, 1415-1428. [CrossRef] [PubMed]

55. Zhao, Y.; Garcia, B.A. Comprehensive Catalog of Currently Documented Histone Modifications. Cold Spring Harb. Perspect. Biol. 2015, 7, a025064. [CrossRef] [PubMed]

56. Shahbazian, M.D.; Grunstein, M. Functions of site-specific histone acetylation and deacetylation. Annu. Rev. Biochem. 2007, 76, 75-100. [CrossRef] [PubMed]

57. Wang, L.H.; Aberin, M.A.E.; Wu, S.; Wang, S.P. The MLL3/4 H3K4 methyltransferase complex in establishing an active enhancer landscape. Biochem. Soc. Trans. 2021, 49, 1041-1054. [CrossRef] [PubMed]

58. Shpargel, K.B.; Sengoku, T.; Yokoyama, S.; Magnuson, T. UTX and UTY demonstrate histone demethylase-independent function in mouse embryonic development. PLoS Genet. 2012, 8, e1002964. [CrossRef] [PubMed]

59. Walport, L.J.; Hopkinson, R.J.; Vollmar, M.; Madden, S.K.; Gileadi, C.; Oppermann, U.; Schofield, C.J.; Johansson, C. Human $\mathrm{UTY}(\mathrm{KDM} 6 \mathrm{C})$ is a male-specific N-methyl lysyl demethylase. J. Biol. Chem. 2014, 289, 18302-18313. [CrossRef] [PubMed]

60. Centore, R.C.; Sandoval, G.J.; Soares, L.M.M.; Kadoch, C.; Chan, H.M. Mammalian SWI/SNF Chromatin Remodeling Complexes: Emerging Mechanisms and Therapeutic Strategies. Trends Genet. 2020, 36, 936-950. [CrossRef] [PubMed]

61. Kadoch, C.; Hargreaves, D.C.; Hodges, C.; Elias, L.; Ho, L.; Ranish, J.; Crabtree, G.R. Proteomic and bioinformatic analysis of mammalian SWI/SNF complexes identifies extensive roles in human malignancy. Nat. Genet. 2013, 45, 592-601. [CrossRef] [PubMed]

62. Romero, O.A.; Sanchez-Cespedes, M. The SWI/SNF genetic blockade: Effects in cell differentiation, cancer and developmental diseases. Oncogene 2014, 33, 2681-2689. [CrossRef] [PubMed]

63. Skulte, K.A.; Phan, L.; Clark, S.J.; Taberlay, P.C. Chromatin remodeler mutations in human cancers: Epigenetic implications. Epigenomics 2014, 6, 397-414. [CrossRef]

64. Wilson, B.G.; Roberts, C.W. SWI/SNF nucleosome remodellers and cancer. Nat. Rev. Cancer 2011, 11, 481-492. [CrossRef] [PubMed]

65. Alpsoy, A.; Sood, S.; Dykhuizen, E.C. At the Crossroad of Gene Regulation and Genome Organization: Potential Roles for ATP-Dependent Chromatin Remodelers in the Regulation of CTCF-Mediated 3D Architecture. Biology 2021, 10, 272. [CrossRef] [PubMed]

66. Rowley, M.J.; Corces, V.G. Organizational principles of 3D genome architecture. Nat. Rev. Genet. 2018, 19, 789-800. [CrossRef]

67. Balbas-Martinez, C.; Sagrera, A.; Carrillo-de-Santa-Pau, E.; Earl, J.; Marquez, M.; Vazquez, M.; Lapi, E.; Castro-Giner, F.; Beltran, S.; Bayes, M.; et al. Recurrent inactivation of STAG2 in bladder cancer is not associated with aneuploidy. Nat. Genet. 2013, 45, 1464-1469. [CrossRef] 
68. Guo, G.; Sun, X.; Chen, C.; Wu, S.; Huang, P.; Li, Z.; Dean, M.; Huang, Y.; Jia, W.; Zhou, Q.; et al. Whole-genome and whole-exome sequencing of bladder cancer identifies frequent alterations in genes involved in sister chromatid cohesion and segregation. Nat. Genet. 2013, 45, 1459-1463. [CrossRef]

69. Solomon, D.A.; Kim, J.S.; Bondaruk, J.; Shariat, S.F.; Wang, Z.F.; Elkahloun, A.G.; Ozawa, T.; Gerard, J.; Zhuang, D.; Zhang, S.; et al. Frequent truncating mutations of STAG2 in bladder cancer. Nat. Genet. 2013, 45, 1428-1430. [CrossRef]

70. Casa, V.; Moronta Gines, M.; Gade Gusmao, E.; Slotman, J.A.; Zirkel, A.; Josipovic, N.; Oole, E.; van, I.W.F.J.; Houtsmuller, A.B.; Papantonis, A.; et al. Redundant and specific roles of cohesin STAG subunits in chromatin looping and transcriptional control. Genome Res. 2020, 30, 515-527. [CrossRef]

71. Hill, V.K.; Kim, J.S.; Waldman, T. Cohesin mutations in human cancer. BBA Rev. Cancer 2016, 1866, 1-11. [CrossRef] [PubMed]

72. Kim, K.; Punj, V.; Choi, J.; Heo, K.; Kim, J.M.; Laird, P.W.; An, W. Gene dysregulation by histone variant H2A.Z in bladder cancer. Epigenetics Chromatin 2013, 6, 34. [CrossRef] [PubMed]

73. Singh, R.; Harshman, S.W.; Ruppert, A.S.; Mortazavi, A.; Lucas, D.M.; Thomas-Ahner, J.M.; Clinton, S.K.; Byrd, J.C.; Freitas, M.A.; Parthun, M.R. Proteomic profiling identifies specific histone species associated with leukemic and cancer cells. Clin. Proteom. 2015, 12, 22. [CrossRef]

74. Mercer, T.R.; Mattick, J.S. Structure and function of long noncoding RNAs in epigenetic regulation. Nat. Struct. Mol. Biol. 2013, 20, 300-307. [CrossRef] [PubMed]

75. Hammouz, R.Y.; Kolat, D.; Kaluzinska, Z.; Pluciennik, E.; Bednarek, A.K. MicroRNAs: Their Role in Metastasis, Angiogenesis, and the Potential for Biomarker Utility in Bladder Carcinomas. Cancers 2021, 13, 891. [CrossRef] [PubMed]

76. Taheri, M.; Shirvani-Farsani, Z.; Ghafouri-Fard, S.; Omrani, M.D. Expression profile of microRNAs in bladder cancer and their application as biomarkers. Biomed. Pharmacother. 2020, 131, 110703. [CrossRef] [PubMed]

77. Nordentoft, I.; Lamy, P.; Birkenkamp-Demtroder, K.; Shumansky, K.; Vang, S.; Hornshoj, H.; Juul, M.; Villesen, P.; Hedegaard, J.; Roth, A.; et al. Mutational context and diverse clonal development in early and late bladder cancer. Cell Rep. 2014, 7, 1649-1663. [CrossRef] [PubMed]

78. Casadevall, D.; Kilian, A.Y.; Bellmunt, J. The prognostic role of epigenetic dysregulation in bladder cancer: A systematic review. Cancer Treat. Rev. 2017, 61, 82-93. [CrossRef] [PubMed]

79. Schulz, W.A.; Lang, A.; Koch, J.; Greife, A. The histone demethylase UTX/KDM6A in cancer: Progress and puzzles. Int. J. Cancer 2019, 145, 614-620. [CrossRef] [PubMed]

80. Medvedeva, Y.A.; Lennartsson, A.; Ehsani, R.; Kulakovskiy, I.V.; Vorontsov, I.E.; Panahandeh, P.; Khimulya, G.; Kasukawa, T.; Consortium, F.; Drablos, F. EpiFactors: A comprehensive database of human epigenetic factors and complexes. Database 2015, 2015, bav067. [CrossRef] [PubMed]

81. Cerami, E.; Gao, J.; Dogrusoz, U.; Gross, B.E.; Sumer, S.O.; Aksoy, B.A.; Jacobsen, A.; Byrne, C.J.; Heuer, M.L.; Larsson, E.; et al. The cBio cancer genomics portal: An open platform for exploring multidimensional cancer genomics data. Cancer Discov. 2012, 2, 401-404. [CrossRef]

82. Gao, J.; Aksoy, B.A.; Dogrusoz, U.; Dresdner, G.; Gross, B.; Sumer, S.O.; Sun, Y.; Jacobsen, A.; Sinha, R.; Larsson, E.; et al. Integrative analysis of complex cancer genomics and clinical profiles using the cBioPortal. Sci. Signal. 2013, 6, pl1. [CrossRef] [PubMed]

83. Weilandt, M.; Koch, A.; Rieder, H.; Deenen, R.; Schwender, H.; Niegisch, G.; Schulz, W.A. Target genes of recurrent chromosomal amplification and deletion in urothelial carcinoma. Cancer Genom. Proteom. 2014, 11, 141-153.

84. Shen, H.; Morrison, C.D.; Zhang, J.; Underwood, W., 3rd; Yang, N.; Frangou, C.; Eng, K.; Head, K.; Bollag, R.J.; Kavuri, S.K.; et al. 6p22.3 amplification as a biomarker and potential therapeutic target of advanced stage bladder cancer. Oncotarget 2013, 4, 2124-2134. [CrossRef]

85. Evans, A.J.; Gallie, B.L.; Jewett, M.A.; Pond, G.R.; Vandezande, K.; Underwood, J.; Fradet, Y.; Lim, G.; Marrano, P.; Zielenska, M.; et al. Defining a 0.5-mb region of genomic gain on chromosome $6 \mathrm{p} 22$ in bladder cancer by quantitative-multiplex polymerase chain reaction. Am. J. Pathol. 2004, 164, 285-293. [CrossRef]

86. Chen, Y.; Zhou, B.; Chen, D. USP21 promotes cell proliferation and metastasis through suppressing EZH2 ubiquitination in bladder carcinoma. Onco. Targets Ther. 2017, 10, 681-689. [CrossRef] [PubMed]

87. Liu, J.; Kruswick, A.; Dang, H.; Tran, A.D.; Kwon, S.M.; Wang, X.W.; Oberdoerffer, P. Ubiquitin-specific protease 21 stabilizes BRCA2 to control DNA repair and tumor growth. Nat. Commun. 2017, 8, 137. [CrossRef]

88. Riester, M.; Werner, L.; Bellmunt, J.; Selvarajah, S.; Guancial, E.A.; Weir, B.A.; Stack, E.C.; Park, R.S.; O’Brien, R.; Schutz, F.A.; et al. Integrative analysis of 1q23.3 copy-number gain in metastatic urothelial carcinoma. Clin. Cancer Res. 2014, 20, $1873-1883$. [CrossRef] [PubMed]

89. Lindgren, D.; Sjodahl, G.; Lauss, M.; Staaf, J.; Chebil, G.; Lovgren, K.; Gudjonsson, S.; Liedberg, F.; Patschan, O.; Mansson, W.; et al. Integrated genomic and gene expression profiling identifies two major genomic circuits in urothelial carcinoma. PLoS ONE 2012, 7, e38863. [CrossRef] [PubMed]

90. Strepkos, D.; Markouli, M.; Klonou, A.; Papavassiliou, A.G.; Piperi, C. Histone Methyltransferase SETDB1: A Common Denominator of Tumorigenesis with Therapeutic Potential. Cancer Res. 2021, 81, 525-534. [CrossRef] [PubMed]

91. Liu, S.; Jiang, H.; Wen, H.; Ding, Q.; Feng, C. Knockdown of tyrosine 3-monooxygenase/tryptophan 5-monooxygenase activation protein zeta (YWHAZ) enhances tumorigenesis both in vivo and in vitro in bladder cancer. Oncol. Rep. 2018, 39, $2127-2135$. [CrossRef] [PubMed] 
92. Shearer, R.F.; Iconomou, M.; Watts, C.K.; Saunders, D.N. Functional Roles of the E3 Ubiquitin Ligase UBR5 in Cancer. Mol. Cancer Res. 2015, 13, 1523-1532. [CrossRef] [PubMed]

93. Gudjonsson, T.; Altmeyer, M.; Savic, V.; Toledo, L.; Dinant, C.; Grofte, M.; Bartkova, J.; Poulsen, M.; Oka, Y.; Bekker-Jensen, S.; et al. TRIP12 and UBR5 suppress spreading of chromatin ubiquitylation at damaged chromosomes. Cell 2012, 150, 697-709. [CrossRef] [PubMed]

94. Hoglund, M. The bladder cancer genome; chromosomal changes as prognostic makers, opportunities, and obstacles. Urol. Oncol. 2012, 30, 533-540. [CrossRef] [PubMed]

95. Abedin, S.A.; Thorne, J.L.; Battaglia, S.; Maguire, O.; Hornung, L.B.; Doherty, A.P.; Mills, I.G.; Campbell, M.J. Elevated NCOR1 disrupts a network of dietary-sensing nuclear receptors in bladder cancer cells. Carcinogenesis 2009, 30, 449-456. [CrossRef] [PubMed]

96. Battaglia, S.; Maguire, O.; Thorne, J.L.; Hornung, L.B.; Doig, C.L.; Liu, S.; Sucheston, L.E.; Bianchi, A.; Khanim, F.L.; Gommersall, L.M.; et al. Elevated NCOR1 disrupts PPARalpha/gamma signaling in prostate cancer and forms a targetable epigenetic lesion. Carcinogenesis 2010, 31, 1650-1660. [CrossRef] [PubMed]

97. Li, L.; Liu, X.; He, L.; Yang, J.; Pei, F.; Li, W.; Liu, S.; Chen, Z.; Xie, G.; Xu, B.; et al. ZNF516 suppresses EGFR by targeting the CtBP/LSD1/CoREST complex to chromatin. Nat. Commun. 2017, 8, 691. [CrossRef] [PubMed]

98. Mishima, Y.; Miyagi, S.; Saraya, A.; Negishi, M.; Endoh, M.; Endo, T.A.; Toyoda, T.; Shinga, J.; Katsumoto, T.; Chiba, T.; et al. The Hbo1-Brd1/Brpf2 complex is responsible for global acetylation of H3K14 and required for fetal liver erythropoiesis. Blood 2011, 118, 2443-2453. [CrossRef]

99. Rosik, L.; Niegisch, G.; Fischer, U.; Jung, M.; Schulz, W.A.; Hoffmann, M.J. Limited efficacy of specific HDAC6 inhibition in urothelial cancer cells. Cancer Biol. Ther. 2014, 15, 742-757. [CrossRef] [PubMed]

100. Xing, J.; Dinney, C.P.; Shete, S.; Huang, M.; Hildebrandt, M.A.; Chen, Z.; Gu, J. Comprehensive pathway-based interrogation of genetic variations in the nucleotide excision DNA repair pathway and risk of bladder cancer. Cancer 2012, 118, 205-215. [CrossRef]

101. Szklarczyk, D.; Gable, A.L.; Nastou, K.C.; Lyon, D.; Kirsch, R.; Pyysalo, S.; Doncheva, N.T.; Legeay, M.; Fang, T.; Bork, P.; et al. The STRING database in 2021: Customizable protein-protein networks, and functional characterization of user-uploaded gene/measurement sets. Nucleic Acids Res. 2021, 49, D605-D612. [CrossRef] [PubMed]

102. Ide, H.; Goto, T.; Teramoto, Y.; Mizushima, T.; Jiang, G.; Nagata, Y.; Inoue, S.; Baras, A.S.; Kashiwagi, E.; Miyamoto, H. FOXO1 inactivation induces cisplatin resistance in bladder cancer. Cancer Sci. 2020, 111, 3397-3400. [CrossRef] [PubMed]

103. Lloreta, J.; Font-Tello, A.; Juanpere, N.; Frances, A.; Lorenzo, M.; Nonell, L.; de Muga, S.; Vazquez, I.; Cecchini, L.; HernandezLlodra, S. FOXO1 down-regulation is associated with worse outcome in bladder cancer and adds significant prognostic information to p53 overexpression. Hum. Pathol. 2017, 62, 222-231. [CrossRef] [PubMed]

104. Wang, C.; Hamacher, A.; Petzsch, P.; Kohrer, K.; Niegisch, G.; Hoffmann, M.J.; Schulz, W.A.; Kassack, M.U. Combination of Decitabine and Entinostat Synergistically Inhibits Urothelial Bladder Cancer Cells via Activation of FoxO1. Cancers 2020, 12, 377. [CrossRef] [PubMed]

105. Casamassimi, A.; Rienzo, M.; Di Zazzo, E.; Sorrentino, A.; Fiore, D.; Proto, M.C.; Moncharmont, B.; Gazzerro, P.; Bifulco, M.; Abbondanza, C. Multifaceted Role of PRDM Proteins in Human Cancer. Int. J. Mol. Sci. 2020, 21, 2648. [CrossRef] [PubMed]

106. Cheng, L.; Zhang, X.; Wang, Y.; Gan, H.; Xu, X.; Lv, X.; Hua, X.; Que, J.; Ordog, T.; Zhang, Z. Chromatin Assembly Factor 1 (CAF-1) facilitates the establishment of facultative heterochromatin during pluripotency exit. Nucleic Acids Res. 2019, 47, 11114-11131. [CrossRef] [PubMed]

107. Ishiuchi, T.; Abe, S.; Inoue, K.; Yeung, W.K.A.; Miki, Y.; Ogura, A.; Sasaki, H. Reprogramming of the histone H3.3 landscape in the early mouse embryo. Nat. Struct. Mol. Biol. 2021, 28, 38-49. [CrossRef]

108. Bracken, A.P.; Pasini, D.; Capra, M.; Prosperini, E.; Colli, E.; Helin, K. EZH2 is downstream of the pRB-E2F pathway, essential for proliferation and amplified in cancer. EMBO J. 2003, 22, 5323-5335. [CrossRef]

109. Hinz, S.; Kempkensteffen, C.; Christoph, F.; Hoffmann, M.; Krause, H.; Schrader, M.; Schostak, M.; Miller, K.; Weikert, S. Expression of the polycomb group protein EZH2 and its relation to outcome in patients with urothelial carcinoma of the bladder. J. Cancer Res. Clin. Oncol. 2008, 134, 331-336. [CrossRef] [PubMed]

110. Jeitany, M.; Bakhos-Douaihy, D.; Silvestre, D.C.; Pineda, J.R.; Ugolin, N.; Moussa, A.; Gauthier, L.R.; Busso, D.; Junier, M.P.; Chneiweiss, H.; et al. Opposite effects of GCN5 and PCAF knockdowns on the alternative mechanism of telomere maintenance. Oncotarget 2017, 8, 26269-26280. [CrossRef]

111. Koutsogiannouli, E.A.; Wagner, N.; Hader, C.; Pinkerneil, M.; Hoffmann, M.J.; Schulz, W.A. Differential Effects of Histone Acetyltransferase GCN5 or PCAF Knockdown on Urothelial Carcinoma Cells. Int J. Mol. Sci. 2017, 18, 1449. [CrossRef] [PubMed]

112. DeGraff, D.J.; Clark, P.E.; Cates, J.M.; Yamashita, H.; Robinson, V.L.; Yu, X.; Smolkin, M.E.; Chang, S.S.; Cookson, M.S.; Herrick, M.K.; et al. Loss of the urothelial differentiation marker FOXA1 is associated with high grade, late stage bladder cancer and increased tumor proliferation. PLoS ONE 2012, 7, e36669. [CrossRef]

113. Warrick, J.I.; Walter, V.; Yamashita, H.; Chung, E.; Shuman, L.; Amponsa, V.O.; Zheng, Z.; Chan, W.; Whitcomb, T.L.; Yue, F.; et al. FOXA1, GATA3 and PPAR Cooperate to Drive Luminal Subtype in Bladder Cancer: A Molecular Analysis of Established Human Cell Lines. Sci. Rep. 2016, 6, 38531. [CrossRef] [PubMed] 
114. Buckwalter, J.M.; Chan, W.; Shuman, L.; Wildermuth, T.; Ellis-Mohl, J.; Walter, V.; Warrick, J.I.; Wu, X.R.; Kaag, M.; Raman, J.D.; et al. Characterization of Histone Deacetylase Expression Within In Vitro and In Vivo Bladder Cancer Model Systems. Int. J. Mol. Sci. 2019, 20, 2599. [CrossRef] [PubMed]

115. Jaguva Vasudevan, A.A.; Hoffmann, M.J.; Beck, M.L.C.; Poschmann, G.; Petzsch, P.; Wiek, C.; Stuhler, K.; Kohrer, K.; Schulz, W.A.; Niegisch, G. HDAC5 Expression in Urothelial Carcinoma Cell Lines Inhibits Long-Term Proliferation but Can Promote Epithelialto-Mesenchymal Transition. Int. J. Mol. Sci. 2019, 20, 2135. [CrossRef]

116. Shrestha, S.; Adhikary, G.; Xu, W.; Kandasamy, S.; Eckert, R.L. ACTL6A suppresses p21(Cip1) expression to enhance the epidermal squamous cell carcinoma phenotype. Oncogene 2020, 39, 5855-5866. [CrossRef] [PubMed]

117. Lim, N.; Townsend, P.A. Cdc6 as a novel target in cancer: Oncogenic potential, senescence and subcellular localisation. Int. J. Cancer 2020, 147, 1528-1534. [CrossRef]

118. Chen, S.; Chen, X.; Xie, G.; He, Y.; Yan, D.; Zheng, D.; Li, S.; Fu, X.; Li, Y.; Pang, X.; et al. Cdc6 contributes to cisplatin-resistance by activation of ATR-Chk1 pathway in bladder cancer cells. Oncotarget 2016, 7, 40362-40376. [CrossRef]

119. Evans, C.M.; Phillips, M.; Malone, K.L.; Tonelli, M.; Cornilescu, G.; Cornilescu, C.; Holton, S.J.; Gorjanacz, M.; Wang, L.; Carlson, S.; et al. Coordination of Di-Acetylated Histone Ligands by the ATAD2 Bromodomain. Int. J. Mol. Sci. 2021, 22, 9128. [CrossRef] [PubMed]

120. Nayak, A.; Dutta, M.; Roychowdhury, A. Emerging oncogene ATAD2: Signaling cascades and therapeutic initiatives. Life Sci 2021, 276, 119322. [CrossRef] [PubMed]

121. Huang, H.; Lee, M.H.; Liu, K.; Dong, Z.; Ryoo, Z.; Kim, M.O. PBK/TOPK: An Effective Drug Target with Diverse Therapeutic Potential. Cancers 2021, 13, 2232. [CrossRef] [PubMed]

122. Cao, R.; Wang, G.; Qian, K.; Chen, L.; Qian, G.; Xie, C.; Dan, H.C.; Jiang, W.; Wu, M.; Wu, C.L.; et al. Silencing of HJURP induces dysregulation of cell cycle and ROS metabolism in bladder cancer cells via PPARgamma-SIRT1 feedback loop. J. Cancer 2017, 8, 2282-2295. [CrossRef] [PubMed]

123. Singh, P.K.; Srivastava, A.K.; Dalela, D.; Rath, S.K.; Goel, M.M.; Bhatt, M.L. Expression of PDZ-binding kinase/T-LAK celloriginated protein kinase (PBK/TOPK) in human urinary bladder transitional cell carcinoma. Immunobiology 2014, 219, 469-474. [CrossRef] [PubMed]

124. Zhao, Z.; Shilatifard, A. Epigenetic modifications of histones in cancer. Genome Biol. 2019, 20, 245. [CrossRef] [PubMed]

125. Cenik, B.K.; Shilatifard, A. COMPASS and SWI/SNF complexes in development and disease. Nat. Rev. Genet. 2021, 22, 38-58. [CrossRef]

126. Schuettengruber, B.; Bourbon, H.M.; Di Croce, L.; Cavalli, G. Genome Regulation by Polycomb and Trithorax: 70 Years and Counting. Cell 2017, 171, 34-57. [CrossRef] [PubMed]

127. Steffen, P.A.; Ringrose, L. What are memories made of? How Polycomb and Trithorax proteins mediate epigenetic memory. Nat. Rev. Mol. Cell Biol. 2014, 15, 340-356. [CrossRef] [PubMed]

128. Martinez-Fernandez, M.; Duenas, M.; Feber, A.; Segovia, C.; Garcia-Escudero, R.; Rubio, C.; Lopez-Calderon, F.F.; Diaz-Garcia, C.; Villacampa, F.; Duarte, J.; et al. A Polycomb-mir200 loop regulates clinical outcome in bladder cancer. Oncotarget 2015, 6, 42258-42275. [CrossRef]

129. Eckert, R.L.; Adhikary, G.; Rorke, E.A.; Chew, Y.C.; Balasubramanian, S. Polycomb group proteins are key regulators of keratinocyte function. J. Investig. Dermatol. 2011, 131, 295-301. [CrossRef] [PubMed]

130. Cohen, I.; Zhao, D.; Menon, G.; Nakayama, M.; Koseki, H.; Zheng, D.; Ezhkova, E. PRC1 preserves epidermal tissue integrity independently of PRC2. Genes Dev. 2019, 33, 55-60. [CrossRef] [PubMed]

131. Pena-Llopis, S.; Vega-Rubin-de-Celis, S.; Liao, A.; Leng, N.; Pavia-Jimenez, A.; Wang, S.; Yamasaki, T.; Zhrebker, L.; Sivanand, S.; Spence, P.; et al. BAP1 loss defines a new class of renal cell carcinoma. Nat. Genet. 2012, 44, 751-759. [CrossRef]

132. Nickerson, M.L.; Dancik, G.M.; Im, K.M.; Edwards, M.G.; Turan, S.; Brown, J.; Ruiz-Rodriguez, C.; Owens, C.; Costello, J.C.; Guo, G.; et al. Concurrent alterations in TERT, KDM6A, and the BRCA pathway in bladder cancer. Clin. Cancer Res. 2014, 20, 4935-4948. [CrossRef]

133. Campagne, A.; Lee, M.K.; Zielinski, D.; Michaud, A.; Le Corre, S.; Dingli, F.; Chen, H.; Shahidian, L.Z.; Vassilev, I.; Servant, N.; et al. BAP1 complex promotes transcription by opposing PRC1-mediated H2A ubiquitylation. Nat. Commun. 2019, 10, 348. [CrossRef]

134. Louie, B.H.; Kurzrock, R. BAP1: Not just a BRCA1-associated protein. Cancer Treat. Rev. 2020, 90, 102091. [CrossRef]

135. Borcsok, J.; Diossy, M.; Sztupinszki, Z.; Prosz, A.; Tisza, V.; Spisak, S.; Rusz, O.; Stormoen, D.R.; Pappot, H.; Csabai, I.; et al. Detection of Molecular Signatures of Homologous Recombination Deficiency in Bladder Cancer. Clin. Cancer Res. 2021, 27, 3734-3743. [CrossRef] [PubMed]

136. Lee, J.; Kim, D.H.; Lee, S.; Yang, Q.H.; Lee, D.K.; Lee, S.K.; Roeder, R.G.; Lee, J.W. A tumor suppressive coactivator complex of p53 containing ASC-2 and histone H3-lysine-4 methyltransferase MLL3 or its paralogue MLL4. Proc. Natl. Acad. Sci. USA 2009, 106, 8513-8518. [CrossRef]

137. Rampias, T.; Karagiannis, D.; Avgeris, M.; Polyzos, A.; Kokkalis, A.; Kanaki, Z.; Kousidou, E.; Tzetis, M.; Kanavakis, E.; Stravodimos, K.; et al. The lysine-specific methyltransferase KMT2C/MLL3 regulates DNA repair components in cancer. EMBO Rep. 2019, 20, e46821. [CrossRef] [PubMed] 
138. Grivas, P.; Loriot, Y.; Morales-Barrera, R.; Teo, M.Y.; Zakharia, Y.; Feyerabend, S.; Vogelzang, N.J.; Grande, E.; Adra, N.; Alva, A.; et al. Efficacy and safety of rucaparib in previously treated, locally advanced or metastatic urothelial carcinoma from a phase 2, open-label trial (ATLAS). BMC Cancer 2021, 21, 593. [CrossRef] [PubMed]

139. Alves-Fernandes, D.K.; Jasiulionis, M.G. The Role of SIRT1 on DNA Damage Response and Epigenetic Alterations in Cancer. Int. J. Mol. Sci. 2019, 20, 3153. [CrossRef]

140. Carafa, V.; Rotili, D.; Forgione, M.; Cuomo, F.; Serretiello, E.; Hailu, G.S.; Jarho, E.; Lahtela-Kakkonen, M.; Mai, A.; Altucci, L. Sirtuin functions and modulation: From chemistry to the clinic. Clin. Epigenetics 2016, 8, 61. [CrossRef] [PubMed]

141. Tan, P.; Wang, M.; Zhong, A.; Wang, Y.; Du, J.; Wang, J.; Qi, L.; Bi, Z.; Zhang, P.; Lin, T.; et al. SRT1720 inhibits the growth of bladder cancer in organoids and murine models through the SIRT1-HIF axis. Oncogene 2021, 40, 6081-6092. [CrossRef] [PubMed]

142. Peng, T.; Wang, G.; Cheng, S.; Xiong, Y.; Cao, R.; Qian, K.; Ju, L.; Wang, X.; Xiao, Y. The role and function of PPARgamma in bladder cancer. J. Cancer 2020, 11, 3965-3975. [CrossRef] [PubMed]

143. Antunes, E.T.B.; Ottersbach, K. The MLL/SET family and haematopoiesis. Biochim. Biophys. Acta Gene Regul. Mech. 2020, 1863, 194579. [CrossRef] [PubMed]

144. Barrows, D.; Feng, L.; Carroll, T.S.; Allis, C.D. Loss of UTX/KDM6A and the activation of FGFR3 converge to regulate differentiation gene-expression programs in bladder cancer. Proc. Natl. Acad. Sci. USA 2020, 117, 25732-25741. [CrossRef]

145. Guo, C.; Balsara, Z.R.; Hill, W.G.; Li, X. Stage- and subunit-specific functions of polycomb repressive complex 2 in bladder urothelial formation and regeneration. Development 2017, 144, 400-408. [CrossRef]

146. Dudziec, E.; Gogol-Doring, A.; Cookson, V.; Chen, W.; Catto, J. Integrated epigenome profiling of repressive histone modifications, DNA methylation and gene expression in normal and malignant urothelial cells. PLoS ONE 2012, 7, e32750. [CrossRef] [PubMed]

147. Sen, G.L.; Webster, D.E.; Barragan, D.I.; Chang, H.Y.; Khavari, P.A. Control of differentiation in a self-renewing mammalian tissue by the histone demethylase JMJD3. Genes Dev. 2008, 22, 1865-1870. [CrossRef] [PubMed]

148. Lang, A.; Whongsiri, P.; Yilmaz, M.; Lautwein, T.; Petzsch, P.; Greife, A.; Gunes, C.; Köhrer, K.; Niegisch, G.; Hoffmann, M.; et al. Knockdown of UTX/KDM6A Enriches Precursor Cell Populations in Urothelial Cell Cultures and Cell Lines. Cancers 2020, 12, 1023. [CrossRef] [PubMed]

149. Garcia-Martinez, L.; Zhang, Y.; Nakata, Y.; Chan, H.L.; Morey, L. Epigenetic mechanisms in breast cancer therapy and resistance. Nat. Commun. 2021, 12, 1786. [CrossRef] [PubMed]

150. Iyyanki, T.; Zhang, B.; Wang, Q.; Hou, Y.; Jin, Q.; Xu, J.; Yang, H.; Liu, T.; Wang, X.; Song, F.; et al. Subtype-associated epigenomic landscape and 3D genome structure in bladder cancer. Genome Biol. 2021, 22, 105. [CrossRef]

151. Osei-Amponsa, V.; Buckwalter, J.M.; Shuman, L.; Zheng, Z.; Yamashita, H.; Walter, V.; Wildermuth, T.; Ellis-Mohl, J.; Liu, C.; Warrick, J.I.; et al. Hypermethylation of FOXA1 and allelic loss of PTEN drive squamous differentiation and promote heterogeneity in bladder cancer. Oncogene 2020, 39, 1302-1317. [CrossRef] [PubMed]

152. Tate, T.; Xiang, T.N.; Wobker, S.E.; Zhou, M.; Chen, X.; Kim, H.; Batourina, E.; Lin, C.S.; Kim, W.Y.; Lu, C.; et al. Pparg signaling controls bladder cancer subtype and immune exclusion. Nat. Commun. 2021, 12, 6160. [CrossRef] [PubMed]

153. Egolf, S.; Aubert, Y.; Doepner, M.; Anderson, A.; Maldonado-Lopez, A.; Pacella, G.; Lee, J.; Ko, E.K.; Zou, J.; Lan, Y.; et al. LSD1 Inhibition Promotes Epithelial Differentiation through Derepression of Fate-Determining Transcription Factors. Cell Rep. 2019, 28, 1981-1992. [CrossRef]

154. Aubert, Y.; Egolf, S.; Capell, B.C. The Unexpected Noncatalytic Roles of Histone Modifiers in Development and Disease. Trends Genet. 2019, 35, 645-657. [CrossRef]

155. Kauffman, E.C.; Robinson, B.D.; Downes, M.J.; Powell, L.G.; Lee, M.M.; Scherr, D.S.; Gudas, L.J.; Mongan, N.P. Role of androgen receptor and associated lysine-demethylase coregulators, LSD1 and JMJD2A, in localized and advanced human bladder cancer. Mol. Carcinog. 2011, 50, 931-944. [CrossRef]

156. Rose, M.; Maurer, A.; Wirtz, J.; Bleilevens, A.; Waldmann, T.; Wenz, M.; Eyll, M.; Geelvink, M.; Gereitzig, M.; Ruchel, N.; et al. EGFR activity addiction facilitates anti-ERBB based combination treatment of squamous bladder cancer. Oncogene 2020, 39, 6856-6870. [CrossRef]

157. Ge, Y.; Gomez, N.C.; Adam, R.C.; Nikolova, M.; Yang, H.; Verma, A.; Lu, C.P.; Polak, L.; Yuan, S.; Elemento, O.; et al. Stem Cell Lineage Infidelity Drives Wound Repair and Cancer. Cell 2017, 169, 636-650. [CrossRef]

158. Varley, C.L.; Stahlschmidt, J.; Smith, B.; Stower, M.; Southgate, J. Activation of peroxisome proliferator-activated receptor-gamma reverses squamous metaplasia and induces transitional differentiation in normal human urothelial cells. Am. J. Pathol. 2004, 164, 1789-1798. [CrossRef]

159. Clouston, D.; Lawrentschuk, N. Metaplastic conditions of the bladder. BJU Int. 2013, 112 (Suppl. 2), 27-31. [CrossRef] [PubMed]

160. Dotto, G.P.; Rustgi, A.K. Squamous Cell Cancers: A Unified Perspective on Biology and Genetics. Cancer Cell 2016, $29,622-637$. [CrossRef] [PubMed]

161. Guo, C.C.; Majewski, T.; Zhang, L.; Yao, H.; Bondaruk, J.; Wang, Y.; Zhang, S.; Wang, Z.; Lee, J.G.; Lee, S.; et al. Dysregulation of EMT Drives the Progression to Clinically Aggressive Sarcomatoid Bladder Cancer. Cell Rep. 2019, 27, 1781-1793. [CrossRef]

162. George, J.; Lim, J.S.; Jang, S.J.; Cun, Y.; Ozretic, L.; Kong, G.; Leenders, F.; Lu, X.; Fernandez-Cuesta, L.; Bosco, G.; et al. Comprehensive genomic profiles of small cell lung cancer. Nature 2015, 524, 47-53. [CrossRef] [PubMed]

163. Puca, L.; Vlachostergios, P.J.; Beltran, H. Neuroendocrine Differentiation in Prostate Cancer: Emerging Biology, Models, and Therapies. Cold Spring Harb. Perspect. Med. 2019, 9, a030593. [CrossRef] [PubMed] 
164. Robinson, B.D.; Vlachostergios, P.J.; Bhinder, B.; Liu, W.; Li, K.; Moss, T.J.; Bareja, R.; Park, K.; Tavassoli, P.; Cyrta, J.; et al. Upper tract urothelial carcinoma has a luminal-papillary T-cell depleted contexture and activated FGFR3 signaling. Nat. Commun. 2019, 10, 2977. [CrossRef] [PubMed]

165. Kobatake, K.; Ikeda, K.I.; Nakata, Y.; Yamasaki, N.; Ueda, T.; Kanai, A.; Sentani, K.; Sera, Y.; Hayashi, T.; Koizumi, M.; et al. Kdm6a Deficiency Activates Inflammatory Pathways, Promotes M2 Macrophage Polarization, and Causes Bladder Cancer in Cooperation with p53 Dysfunction. Clin. Cancer Res. 2020, 26, 2065-2079. [CrossRef]

166. Ramakrishnan, S.; Granger, V.; Rak, M.; Hu, Q.; Attwood, K.; Aquila, L.; Krishnan, N.; Osiecki, R.; Azabdaftari, G.; Guru, K.; et al. Inhibition of EZH2 induces NK cell-mediated differentiation and death in muscle-invasive bladder cancer. Cell Death Differ. 2019, 26, 2100-2114. [CrossRef] [PubMed]

167. Segovia, C.; San Jose-Eneriz, E.; Munera-Maravilla, E.; Martinez-Fernandez, M.; Garate, L.; Miranda, E.; Vilas-Zornoza, A.; Lodewijk, I.; Rubio, C.; Segrelles, C.; et al. Inhibition of a G9a/DNMT network triggers immune-mediated bladder cancer regression. Nat. Med. 2019, 25, 1073-1081. [CrossRef] [PubMed]

168. Dunn, J.; Rao, S. Epigenetics and immunotherapy: The current state of play. Mol. Immunol. 2017, 87, 227-239. [CrossRef] [PubMed]

169. Grunewald, C.M.; Schulz, W.A.; Skowron, M.A.; Hoffmann, M.J.; Niegisch, G. Tumor immunotherapy-the potential of epigenetic drugs to overcome resistance. Transl. Cancer Res. 2018, 7, 1151-1160. [CrossRef]

170. Mazzone, R.; Zwergel, C.; Mai, A.; Valente, S. Epi-drugs in combination with immunotherapy: A new avenue to improve anticancer efficacy. Clin. Epigenetics 2017, 9, 59. [CrossRef] [PubMed]

171. Perrier, A.; Didelot, A.; Laurent-Puig, P.; Blons, H.; Garinet, S. Epigenetic Mechanisms of Resistance to Immune Checkpoint Inhibitors. Biomolecules 2020, 10, 1061. [CrossRef] [PubMed]

172. Lawson, A.R.J.; Abascal, F.; Coorens, T.H.H.; Hooks, Y.; O’Neill, L.; Latimer, C.; Raine, K.; Sanders, M.A.; Warren, A.Y.; Mahbubani, K.T.A.; et al. Extensive heterogeneity in somatic mutation and selection in the human bladder. Science 2020, 370, 75-82. [CrossRef] [PubMed]

173. Li, R.; Du, Y.; Chen, Z.; Xu, D.; Lin, T.; Jin, S.; Wang, G.; Liu, Z.; Lu, M.; Chen, X.; et al. Macroscopic somatic clonal expansion in morphologically normal human urothelium. Science 2020, 370, 82-89. [CrossRef]

174. Kakiuchi, N.; Ogawa, S. Clonal expansion in non-cancer tissues. Nat. Rev. Cancer 2021, 21, 239-256. [CrossRef] [PubMed]

175. Jaiswal, S.; Ebert, B.L. Clonal hematopoiesis in human aging and disease. Science 2019, 366. [CrossRef] [PubMed]

176. Chen, R.; Okeyo-Owuor, T.; Patel, R.M.; Casey, E.B.; Cluster, A.S.; Yang, W.; Magee, J.A. Kmt2c mutations enhance HSC self-renewal capacity and convey a selective advantage after chemotherapy. Cell Rep. 2021, 34, 108751. [CrossRef] [PubMed]

177. Halstead, A.M.; Kapadia, C.D.; Bolzenius, J.; Chu, C.E.; Schriefer, A.; Wartman, L.D.; Bowman, G.R.; Arora, V.K. Bladder-cancerassociated mutations in RXRA activate peroxisome proliferator-activated receptors to drive urothelial proliferation. Elife 2017, 6, e30862. [CrossRef]

178. Pinkerneil, M.; Hoffmann, M.J.; Schulz, W.A.; Niegisch, G. HDACs and HDAC Inhibitors in Urothelial Carcinoma-Perspectives for an Antineoplastic Treatment. Curr. Med. Chem. 2017, 24, 4151-4165. [CrossRef] [PubMed]

179. Suraweera, A.; O’Byrne, K.J.; Richard, D.J. Combination Therapy With Histone Deacetylase Inhibitors (HDACi) for the Treatment of Cancer: Achieving the Full Therapeutic Potential of HDACi. Front. Oncol. 2018, 8, 92. [CrossRef] [PubMed]

180. Cruz, F.D.; Matushansky, I. Solid tumor differentiation therapy-Is it possible? Oncotarget 2012, 3, 559-567. [CrossRef] [PubMed]

181. Ahn, J.; Kim, K.H.; Park, S.; Ahn, Y.H.; Kim, H.Y.; Yoon, H.; Lee, J.H.; Bang, D.; Lee, D.H. Target sequencing and CRISPR/Cas editing reveal simultaneous loss of UTX and UTY in urothelial bladder cancer. Oncotarget 2016, 7, 63252-63260. [CrossRef] [PubMed]

182. Ler, L.D.; Ghosh, S.; Chai, X.; Thike, A.A.; Heng, H.L.; Siew, E.Y.; Dey, S.; Koh, L.K.; Lim, J.Q.; Lim, W.K.; et al. Loss of tumor suppressor KDM6A amplifies PRC2-regulated transcriptional repression in bladder cancer and can be targeted through inhibition of EZH2. Sci. Transl. Med. 2017, 9, eaai8312. [CrossRef] [PubMed]

183. Helming, K.C.; Wang, X.; Wilson, B.G.; Vazquez, F.; Haswell, J.R.; Manchester, H.E.; Kim, Y.; Kryukov, G.V.; Ghandi, M.; Aguirre, A.J.; et al. ARID1B is a specific vulnerability in ARID1A-mutant cancers. Nat. Med. 2014, 20, 251-254. [CrossRef] [PubMed]

184. Sasaki, M.; Ogiwara, H. Synthetic lethal therapy based on targeting the vulnerability of SWI/SNF chromatin remodeling complex-deficient cancers. Cancer Sci. 2020, 111, 774-782. [CrossRef] [PubMed]

185. Chang, S.; Yim, S.; Park, H. The cancer driver genes IDH1/2, JARID1C/ KDM5C, and UTX/ KDM6A: Crosstalk between histone demethylation and hypoxic reprogramming in cancer metabolism. Exp. Mol. Med. 2019, 51, 1-17. [CrossRef] [PubMed]

186. Duex, J.E.; Swain, K.E.; Dancik, G.M.; Paucek, R.D.; Owens, C.; Churchill, M.E.A.; Theodorescu, D. Functional Impact of Chromatin Remodeling Gene Mutations and Predictive Signature for Therapeutic Response in Bladder Cancer. Mol. Cancer Res. 2018, 16, 69-77. [CrossRef] [PubMed]

187. House, N.C.; Koch, M.R.; Freudenreich, C.H. Chromatin modifications and DNA repair: Beyond double-strand breaks. Front. Genet. 2014, 5, 296. [CrossRef]

188. Jeggo, P.A.; Downs, J.A.; Gasser, S.M. Chromatin modifiers and remodellers in DNA repair and signalling. Philos. Trans. R Soc. B Biol. Sci. 2017, 372, 20160279. [CrossRef] [PubMed]

189. Liu, L.; Cui, J.; Zhao, Y.; Liu, X.; Chen, L.; Xia, Y.; Wang, Y.; Chen, S.; Sun, S.; Shi, B.; et al. KDM6A-ARHGDIB axis blocks metastasis of bladder cancer by inhibiting Rac1. Mol. Cancer 2021, 20, 77. [CrossRef] 
190. Chen, X.; Lin, X.; Pang, G.; Deng, J.; Xie, Q.; Zhang, Z. Significance of KDM6A mutation in bladder cancer immune escape. BMC Cancer 2021, 21, 635. [CrossRef]

191. Gupta, S.; Albertson, D.J.; Parnell, T.J.; Butterfield, A.; Weston, A.; Pappas, L.M.; Dalley, B.; O’Shea, J.M.; Lowrance, W.T.; Cairns, B.R.; et al. Histone Deacetylase Inhibition Has Targeted Clinical Benefit in ARID1A-Mutated Advanced Urothelial Carcinoma. Mol. Cancer Ther. 2019, 18, 185-195. [CrossRef] [PubMed] 